\title{
Progress in Clinical Neurosciences: Charcot-Marie-Tooth Disease and Related Inherited Peripheral Neuropathies
}

\author{
Timothy J. Benstead and Ian A. Grant
}

\begin{abstract}
The classification of Charcot-Marie-Tooth disease and related hereditary motor and sensory neuropathies has evolved to incorporate clinical, electrophysiological and burgeoning molecular genetic information that characterize the many disorders. For several inherited neuropathies, the gene product abnormality is known and for others, candidate genes have been identified. Genetic testing can pinpoint a specific inherited neuropathy for many patients. However, clinical and electrophysiological assessments continue to be essential tools for diagnosis and management of this disease group. This article reviews clinical, electrophysiological, pathological and molecular aspects of hereditary motor and sensory neuropathies.
\end{abstract}

RÉSUMÉ: Maladie de Charcot-Marie-Tooth et neuropathies périphériques héréditaires apparentées. La classification de la maladie de Charcot-Marie-Tooth et des neuropathies sensitivo-motrices héréditaires apparentées a été élargie afin d'inclure l'information clinique, électrophysiologique et moléculaire qui caractérise ces entités. L'anomalie du gène et de la protéine en cause est connue dans plusieurs neuropathies héréditaires alors que dans d'autres des gènes candidats ont été identifiés. Chez plusieurs patients, des tests génétiques peuvent identifier une neuropathies héréditaire spécifique. Cependant, l'évaluation clinique et électrophysiologique demeure l'outil essentiel pour le diagnostic et la prise en charge de ce groupe de maladies. Cet article revoit les aspects cliniques, électrophysiologiques, anatomopathologiques et moléculaires des neuropathies sensitivo-motrices.

Can. J. Neurol. Sci. 2001; 28: 199-214

Inherited peripheral neuropathy as a diagnostic group encompasses a broad range of conditions with many presenting symptoms and signs. Major subtypes include hereditary motor and sensory neuropathies, hereditary sensory and autonomic neuropathies, hereditary motor neuronopathies, and neuropathies related to specific metabolic disorders. This review will focus on the inherited motor and sensory neuropathy subgroup usually referred to as Charcot-Marie-Tooth disease (CMT), for which there has been an explosion of new molecular genetic information over the past decade. Advances in our understanding of the molecular basis of CMT have revealed an enormous diversity in genetic mechanisms that lead to a clinical entity that is relatively uniform in presentation. Clinicians experienced in the diagnosis of neuromuscular diseases can readily identify a patient with CMT by a group of symptoms and signs that fits a classical pattern. Yet, that clinical pattern may be the result of vastly different genetic defects. Accurate diagnostic characterization has evolved from simple pattern recognition to a more complex series of diagnostic steps. Understanding the basis for these steps will be essential for clinicians to participate fully in the management of patients with CMT. This review will summarize the current understanding of clinical, electrophysio- logical, pathological and molecular aspects of the various subtypes of CMT.

\section{CMT: GENERAL CLINICAL FEATURES}

CMT is a common genetic disorder, estimated to be present in 1 in 2500-5000 people. ${ }^{1-4}$ Patients with CMT can present with a broad range of symptoms and signs. Disease expression varies between and within kindreds. However, certain common features are usually seen. CMT produces a distal greater than proximal, lower extremity greater than upper, motor and sensory deficit, in a typical diffuse peripheral neuropathy pattern. Significant asymmetry of symptoms or signs should not be seen, except in hereditary neuropathy with liability to pressure palsies (HNPP). Hereditary neuropathy with liability to pressure palsies, which is

From the Division of Neurology, QEII Health Sciences Centre and Dalhousie University Medical School, Halifax, Nova Scotia, Canada.

ReCEIVED JANUARY 31, 2001. ACCEPTED IN FINAL FORM MAY 15, 2001. Reprint requests to: Timothy J Benstead, Division of Neurology, QEII Health Sciences Centre, 1796 Summer Street, Halifax, Nova Scotia, Canada B3H 3A7 


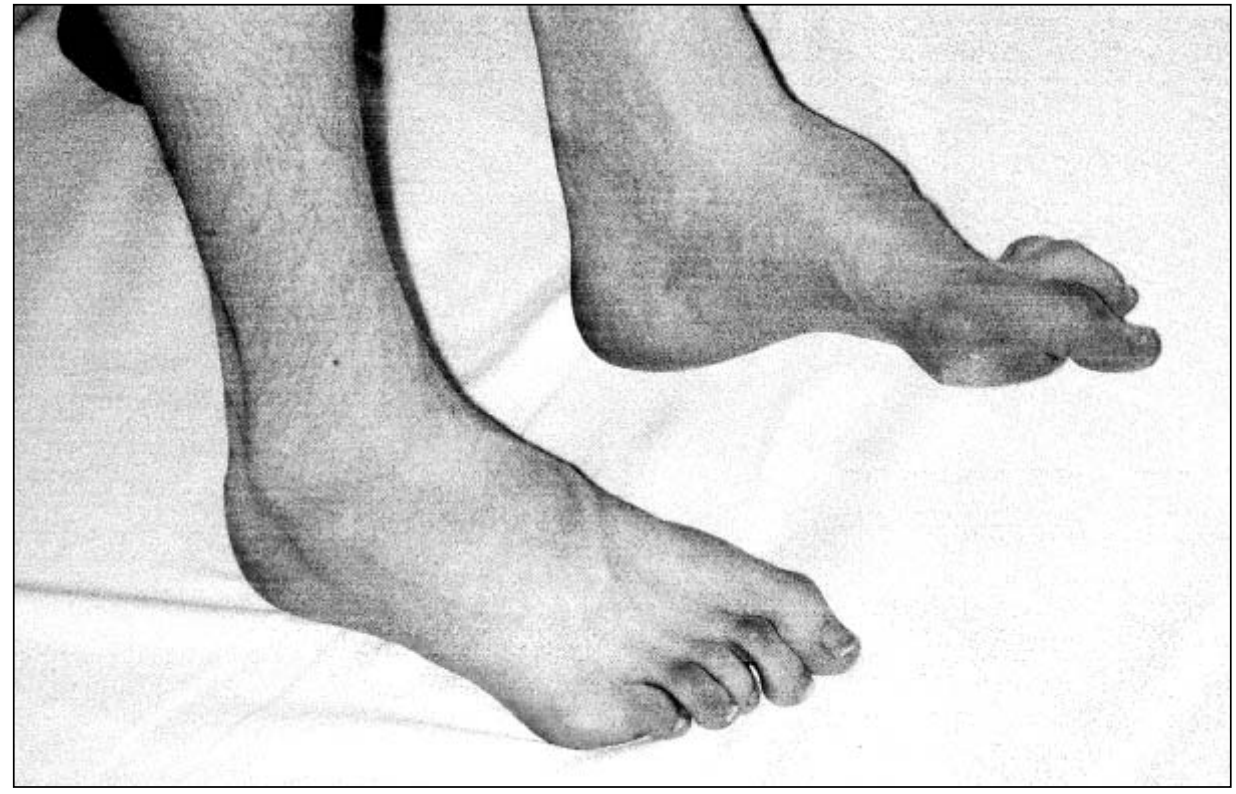

Figure 1: Pes cavus. Twenty-year-old male with CMT 1A. This patient has high plantar arches with hammer toes and atrophy of foot muscles.

discussed in detail later, is not usually considered a form of CMT but it is aligned with this group of disorders by virtue of the abnormality of peripheral myelin, which is the basis of its pathogenesis. Weakness in CMT is usually present in foot and lower leg muscles but is uncommon in upper leg or hip girdle muscles in all but the most severely affected individuals. This means that even patients with marked weakness are still usually able to walk with the aid of ankle splints, due to preserved proximal leg strength. Upper extremity weakness is usually restricted to hand and forearm muscles, which may impair hand function for fine motor and heavy tasks. The sensory loss is glove and stocking in distribution and usually affects all modalities. However, patients are usually less symptomatic from sensory disturbance than motor problems; the early age of onset and slow progression of the sensory deficit likely make sensory loss less apparent to the CMT patient than to a patient with acquired neuropathy. Some patients will deny any sensory symptoms, despite evidence of marked loss of sensation on examination. Paresthesias and neuropathic pain are less common than in acquired sensory motor neuropathies.

Patients usually have foot deformities, most often pes cavus. Pes cavus is recognized by high plantar arches. There is usually wasting of foot muscles and pes cavus is often associated with curled up or "hammer" toes (Figure 1). It is present in the majority of patients with CMT, though it may only be evident as high arches. In a few patients, normal arches or even flat feet may be found. ${ }^{5}$ Pes cavus and hammer toes are characteristic of CMT but are not specific. It can also develop with other forms of chronic inherited neurologic dysfunction beginning during childhood, when bone growth is still active. ${ }^{6,7}$ Occasionally, in longstanding acquired neuropathies developing in adult life, the appearance of the feet can mimic mild pes cavus. Pes cavus will sometimes be seen in patients without neuropathy or other neurologic deficit. Nevertheless, pes cavus remains a very important clinical clue that a neuropathy may be due to an inherited process. Wasting of foot and distal lower extremity muscles develops over time and may produce the classical "inverted champagne bottle" appearance. Some severely affected patients will develop scoliosis, but this is less common in CMT than in inherited muscle disease, where weakness of trunk muscles is a greater problem. In the demyelinating forms of CMT, nerve hypertrophy may be visible and palpable in nerves that are superficially located, such as the greater auricular nerve.

\section{CMT CLASSIFICATION}

Early diagnostic characterization of CMT relied on clinical, electrophysiological and inheritance patterns to divide this disorder into logical subgroups. ${ }^{5,8-10}$ Dyck and Lambert's ${ }^{5}$ classification divided the hereditary motor and sensory neuropathies (HMSN) into HMSN I, II, III, IV, V, VI, VII and X (Table 1).

By the early 1980s, it was clear that multiple genetic abnormalities lead to similar neuropathy phenotypes, such as HMSN I. The earlier HMSN classification was modified to include linkage to chromosome 17 (HMSN IA), chromosome 1 (HMSN IB), the $\mathrm{X}$ chromosome (HMSN X) and unlinked kinships (HMSN IC, etc.). As it became clear that the typical HMSN I and II clinical and electrophysiological features may be seen in patients without autosomal dominant inheritance, the classification scheme was used by some to include patients with nondominant inheritance patterns. ${ }^{11}$ Recessive and sporadic inheritance can be difficult to ascertain, depending on how intensively families are studied and the certainty of parentage. Dyck $^{12}$ demonstrated that intensive evaluation of families could demonstrate unexpected inherited neuropathy in asymptomatic or minimally symptomatic family members. Nevertheless, recessive inheritance in patients with features of HMSN I and II, 
Table 1: Dyck and Lambert classification of hereditary motor and sensory neuropathy (HMSN) ${ }^{5}$

\begin{tabular}{ll}
\hline $\begin{array}{l}\text { Neuropathy Type } \\
\text { HMSN I }\end{array}$ & $\begin{array}{l}\text { Key Neuropathy Features } \\
\text { Autosomal dominant inheritance with low NCV* } \\
\text { Autosomal dominant inheritance with normal or } \\
\text { HMSN II }\end{array}$ \\
low normal NCV \\
Probable autosomal recessive with very low NCV \\
and very severe clinical abnormality
\end{tabular}

*Nerve conduction velocity

Table 2: Current classification of Charcot-Marie-Tooth disease and related neuropathies

\begin{tabular}{|c|c|}
\hline Neuropathy Type & Key Neuropathy Features \\
\hline CMT 1 & Dominantly inherited with low NCV* \\
\hline CMT 2 & $\begin{array}{l}\text { Dominantly inherited with normal or } \\
\text { low normal NCV }\end{array}$ \\
\hline CMT X & X-linked inherited \\
\hline HNPP** & $\begin{array}{l}\text { Dominantly inherited with focal nerve } \\
\text { lesions }\end{array}$ \\
\hline Dejerine-Sottas syndrome & $\begin{array}{l}\text { Variable inheritance with very low } \mathrm{NCV} \\
\text { and severe disability }\end{array}$ \\
\hline Congenital Hypomyelination & $\begin{array}{l}\text { Sporadic inheritance with extremely low } \\
\text { NCV and extremely severe disability }\end{array}$ \\
\hline CMT 4 & Recessively inherited CMT \\
\hline
\end{tabular}

*Nerve conduction velocity, **Hereditary Neuropathy with Liability to Pressure Palsies

from thoroughly assessed kindreds, were well described in the premolecular genetic era. ${ }^{13}$

\section{MoleCUlar CONTRIBUTIONS TO CMT CLASSIFICATION}

The first significant advance toward the current understanding of the molecular basis for CMT came with linkage of families to the Duffy locus on chromosome $1 .^{14,15}$ Linkage to the Duffy locus was designated HMSN IB. Several other families were found to link to chromosome $17 \mathrm{p},{ }^{16}$ designated HMSN IA; some families showed linkage to neither loci. ${ }^{17}$ The families unlinked to chromosome 1 or 17 were given the designation HMSN IC, though how many additional loci will be discovered for the type I phenotype is not known. Subsequently there has been an explosion of molecular information about the various CMT subtypes. It has become apparent that the classification of CMT needs to incorporate clinical, electrophysiological and molecular features. The current diagnostic classification scheme has evolved using a hybrid of earlier eponyms and Dyck and Lambert's scheme (Table 2).
The molecular abnormalities associated with CMT subgroups exhibiting presumed primary myelin dysfunction, suggested by low nerve conduction velocity $(\mathrm{NCV})$, revolve around abnormalities of four key gene products (Table 3). Abnormalities of chromosome $17 \mathrm{p} 11.2-12$ encoding peripheral myelin protein 22 (PMP22), 1q22 encoding myelin $\mathrm{P}_{0}$ protein, Xq13-22 encoding connexin-32 (Cx32) and 10q21.1-22.1 encoding early growth response 2 (EGR2) produce variable phenotypic presentations of neuropathy predominantly with demyelinating features. These proteins are associated with myelin development and function but it is clear that in severely affected myelinated fibres, axonal degeneration will also occur. ${ }^{18,19}$ As noted below, neuropathies associated with $\mathrm{Cx} 32$ mutations may have the electrophysiologic features of an axonal or demyelinating neuropathy and the primary process leading to nerve pathology is less certain.

PMP22 is present in peripheral nervous system compact myelin and constitutes up to $5 \%$ of the total myelin protein content. Its role in myelin function and stability are not completely understood but it contributes to the initial steps of myelin production and maintenance of myelin in peripheral nerves. ${ }^{20} \mathrm{P}_{0}$ protein is the major protein component in peripheral myelin and is responsible for adhesion of compact myelin. ${ }^{21}$ Cx32 is a membrane spanning gap-junction protein that is present in paranodal loops and Schmidt-Lanterman incisures of central and peripheral nervous system myelin. ${ }^{22}$ Connexins form channels that allow diffusion of ions and other molecules between joined cells. Cx32 is likely important for cell-cell interactions between axons and Schwann cells. ${ }^{23}$ The most recent gene product found to be associated with demyelinating neuropathies is EGR2. ${ }^{24}$ EGR2 is a transcription factor involved in gene expression. It contributes to the maturation of Schwann

Table 3: Neuropathies associated with inherited myelin gene defects

\begin{tabular}{ll}
$\begin{array}{l}\text { Myelin Gene Defect } \\
\text { PMP22 } \\
\text { duplication } \\
\text { homozygous duplication } \\
\text { deletion } \\
\text { point mutation }\end{array}$ & Neuropathy \\
Myelin $\mathrm{P}_{0}$ point mutation & HNPP \\
& DSS \\
& CMT 1B \\
& DSS \\
Connexin-32 point mutation & CMT X \\
& CMT 1 \\
EGR2 point mutation & DSS \\
& CH \\
\hline $\begin{array}{l}\text { Abbreviations used: Charcot-Marie-Tooth (CMT), Dejerine-Sottas } \\
\text { syndrome (DSS), congenital hypomyelination (CH), peripheral myelin } \\
\text { protein 22 (PMP22), hereditary neuropathy with liability to pressure } \\
\text { palsies (HNPP), early growth response 2 (EGR2) }\end{array}$
\end{tabular}




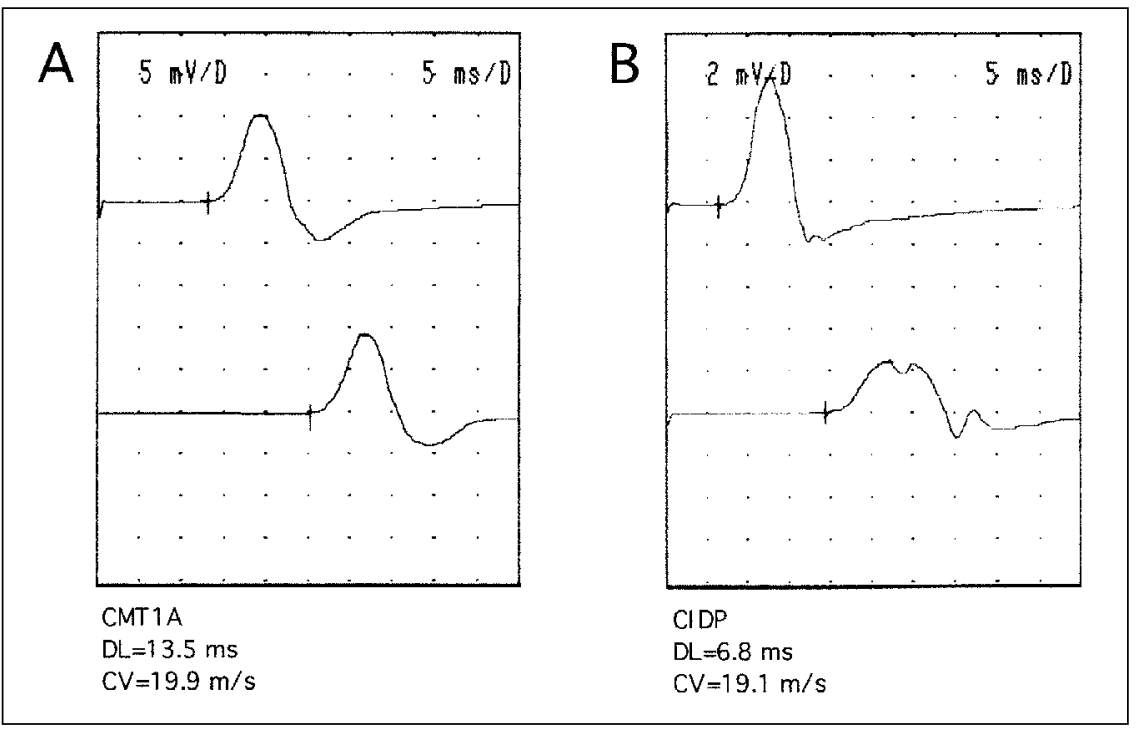

Figure 2: Uniform versus nonuniform conduction slowing of median motor nerve conduction in demyelinating neuropathies. Compound muscle action potentials were recorded from abductor pollicis brevis with stimulation at the wrist (top traces) and elbow (bottom traces). Panel A shows uniform slowing along the forearm segment in a patient with CMT $1 A$. Panel B shows nonuniform slowing with temporal dispersion in a patient with chronic inflammatory demyelinating polyradiculoneuropathy $(C I D P)$. $C V=$ conduction velocity; $D L=$ distal latency.

cells leading to peripheral axonal myelination. ${ }^{25}$ EGR2 mutations are uncommon but already it has become clear that different missense mutations will lead to variable demyelinating neuropathy patterns, including CMT $1,{ }^{24,26}$ Dejerine-Sottas syndrome (DSS), ${ }^{27}$ and congenital hypomyelination $(\mathrm{CH})$ neuropathy. ${ }^{24}$ Most EGR2 mutations have been dominant or sporadic mutations, though recessive inheritance has been described. ${ }^{24}$

There are likely several factors that determine the severity of neuropathy in these demyelinating disorders. For some phenotypes associated with molecular abnormalities of the same gene, gene dosage appears to be important. The neuropathies associated with PMP22 gene abnormalities provide a good example of this gene dosage effect. The level of expression of the PMP22 gene in a patient will dictate the pattern of neuropathy. With one copy of the gene, as occurs with PMP22 deletion, the patient develops HNPP, usually the mildest phenotype of PMP22-related neuropathies. HNPP patients with the deletion have reduced expression of PMP22 in peripheral nerves. ${ }^{28}$ In some HNPP families a frame shift point mutation in the PMP22 gene results in loss of function equivalent to the common deletion, indicating that a reduction in PMP22 dosage is necessary and sufficient for this phenotype. ${ }^{29-31}$ Possessing two copies of the gene is normal. With three copies, resulting from PMP22 duplication, the patient develops CMT $1 \mathrm{~A}$. Immunohistochemical and immunoelectron microscopic studies have demonstrated increased PMP22 expression in CMT 1A due to the chromosome $17 \mathrm{p} 11.2-12$ duplication; ${ }^{32,33}$ and increased PMP22 messenger RNA has been found in nerve biopsy specimens. ${ }^{34}$ These findings provide clues to the gene dosage effect, whereby increased expression of PMP22 (due to the extra functioning gene copy) leads to an excess of PMP22 in the
Schwann cell. It seems clear that the balance of PMP22 expression, reduced in HNPP and increased in CMT 1A, is important in the pathogenesis of these disorders. In CMT 1A, hypermyelination may be an important early stage in the development of eventual demyelination and axon loss, ${ }^{35}$ though the precise mechanisms are not understood. Even greater overexpression of the PMP22 gene, as would be expected with homozygous inheritance of the PMP22 duplication from two CMT 1A parents, leads to a more severe phenotype, suggestive of DSS. ${ }^{36}$

Point mutations of the PMP22 and $\mathrm{P}_{0}$ genes will produce a variety of neuropathy patterns and some will be due to gene underexpression, as in the case of HNPP associated with PMP22 mutation. However, toxic gain of function changes in the gene product have the potential to produce more severe phenotypes, such as DSS and $\mathrm{CH}^{37}$ Other unidentified factors presumably play a role, as family members with identical genotype may have markedly variable phenotype.

\section{CMT 1A}

\section{A) Clinical}

The commonest sub-group of CMT is type 1. In a large group of unrelated CMT patients, $84 \%$ had electrophysiologic features of CMT 1 and, of these, 68\% had the PMP22 duplication of CMT 1A. ${ }^{38}$ The CMT 1A duplication produces a variable clinical presentation with a broad range of clinical severity, evident even within individual families. ${ }^{5,39}$ Despite the existence of severely disabled patients with CMT 1A, the majority of patients with the trait are only mildly to moderately disabled. Many patients will be asymptomatic, though careful examination usually demonstrates signs such as loss of ankle reflexes and foot 
deformity. Birouk ${ }^{39}$ found that in a group of 119 patients with the 17p11.2-12 duplication, about $25 \%$ were asymptomatic and that a very small percentage had severe disability. The onset of patient awareness of symptoms was in the first decade in $50 \%$ and in the first two decades in $70 \%$ of the patients. However, some patients did not experience symptoms until their seventh and eighth decades. In children, difficulty running is often the first symptom. ${ }^{5,39}$ The age of onset of symptoms does correlate with eventual severity and the disease is slowly progressive. ${ }^{39}$ The chromosome 17p11.2-12 duplication will produce atypical presentation in some. In a group of 61 patients with the duplication, eight had the Roussy-Lévy syndrome (CMT plus essential tremor), three had pyramidal signs, one had muscle cramps and calf hypertrophy and one had a predominantly sensory disorder. ${ }^{40}$ The new mutation rate of the PMP22 duplication is about $10 \%,{ }^{41}$ which will account for the lack of family history in some patients. Some patients will develop CMT $1 \mathrm{~A}$ from a PMP22 point mutation. ${ }^{42}$

\section{B) Electrophysiology}

Marked slowing of motor nerve conduction velocities is a hallmark of CMT 1, historically serving as a basis for differentiation of the demyelinating CMT 1 and axonal CMT 2 subtypes. ${ }^{9,43}$ In individuals with CMT 1, Harding and Thomas ${ }^{11}$ found mean median and peroneal motor velocities of 21.1 and $16.6 \mathrm{~m} / \mathrm{s}$ respectively. Comparing median motor conduction velocities in patients with CMT 1 and 2, they found that $38 \mathrm{~m} / \mathrm{s}$ was a useful value in separating these groups. More recent studies in families with documented CMT 1A due to 17p11.2-12 duplications have shown a similar degree of slowing. ${ }^{19,39,44-46}$ Occasional outliers with documented duplications have median velocities above $40 \mathrm{~m} / \mathrm{s} .{ }^{47}$ Motor conduction velocities may be quite variable within individual kindreds, with a range of greater than $20 \mathrm{~m} / \mathrm{s}$ in some families. ${ }^{47}$ Demyelination is also manifested by prolonged distal motor latencies ${ }^{39}$ and prolonged F-wave latencies. ${ }^{47,48}$

Conduction slowing appears very early in life. Penetrance with respect to slowing is complete and may be evident as early as two years of age. ${ }^{48,49}$ The electrophysiologic changes are present in patients with the PMP22 duplication, regardless of the presence or severity of symptoms. In a longitudinal study, Garcia $^{48}$ followed 12 children with CMT 1A, performing clinical and electrophysiologic assessments prior to age five and again approximately seven years thereafter. Children as young as one month of age were included. All children with the duplication displayed nerve conduction abnormalities by age two. Changes were usually present even earlier, with prolonged distal motor latencies preceding conduction slowing in two infants less than 12 months of age. Motor and sensory NCV progressively dropped over time, stabilizing by age five; a finding noted by others. ${ }^{47,49}$ A reduction in compound muscle action potential amplitude was also an early finding, present in recordings from the foot in $50 \%$ of children by age five.

Uniformity of motor conduction slowing has been emphasized as characteristic of CMT $1 .^{19,50-52}$ The underlying demyelinating process affects all myelinated fibres to a similar degree along the entire length of the nerve. Therefore, nerve conduction studies show similar conduction slowing in proximal and distal nerve segments, and among different nerves.
Temporal dispersion and conduction blocks are absent. These findings are diagnostically useful in differentiating CMT 1 from acquired (and some inherited) demyelinating neuropathies in which nonuniform slowing is prominent (Figure 2). ${ }^{51,53}$ Although a few older series reported block in CMT 1 patients, ${ }^{54,55}$ recent large series generally have not confirmed this, instead emphasizing uniformity of slowing. $\mathrm{Kaku}^{52}$ studied 129 patients with CMT 1, including 82 with a confirmed chromosome 17p11.2-12 duplication. A similar reduction in motor NCV was found comparing adjacent upper limb nerves, contralateral nerves and proximal and distal segments of individual nerves. Dispersion and conduction blocks were rare. Using relatively conservative criteria (50\% amplitude difference with proximal versus distal stimulation) dispersion or block was found in only $5.3 \%$ of nerve segments studied. In most instances, this was found in the setting of markedly reduced compound muscle action potential amplitude, suggesting that the observed amplitude change reflected phase cancellation rather than true block. Where block occurred with normal motor amplitudes, the affected site was usually one of common nerve compression (such as the fibular neck). The authors interpreted these findings as indicative of a high degree of uniformity of slowing. Although sensory NCV are less well-studied, they are also reduced in a uniform fashion. ${ }^{19}$

Sensory, and to a lesser degree, motor responses may be absent. Commonly, no sensory potentials can be recorded from the lower limbs and, in advanced cases, from the upper limbs as well. Motor responses are also often absent recording from foot muscles.

Weakness and clinical disability do not appear to correlate well with $\mathrm{NCV},{ }^{19,46}$ although a few studies have noted a correlation. ${ }^{44,56}$ Conduction velocities change little over many years despite progressive neurologic disability. ${ }^{19,46}$ Among eight members of a family studied at a 22-year interval, Killian ${ }^{45}$ noticed a modest mean reduction in motor NCV of $2.2 \mathrm{~m} / \mathrm{s}$ in the median nerve and $3 \mathrm{~m} / \mathrm{s}$ in the peroneal nerve. These findings are consistent with the pathological observation that demyelination is most active in the first five years of life but relatively quiescent thereafter. ${ }^{57}$ Disability correlates better with compound muscle action potential amplitude. ${ }^{19,44,46,56}$ Motor amplitudes gradually decrease over time, in keeping with ongoing axon loss. Median nerve motor unit number estimates also correlate with thenar weakness. ${ }^{19}$ Sensory deficits have been correlated with sensory nerve action potential amplitudes but not sensory NCV. ${ }^{19}$ These findings support the notion that clinical severity relates to underlying axon loss rather than to conduction slowing.

\section{C) Pathology}

Until recently, most information was derived from undifferentiated CMT 1 cases. More recently, pathologic findings in patients with 17p11.2-12 duplications have been reported. Endoneurial area is increased. ${ }^{43,58}$ Onion bulbs, concentric collections of Schwann cell processes surrounding a myelinated or nonmyelinated axon or a regenerating cluster of axons, are characteristic (Figure 3). Overlapping lamellae are separated by collagen bundles. Onion bulbs are poorly developed in childhood, becoming more prominent over time. ${ }^{59,60}$ In advanced cases with severe axon loss, onion bulbs 


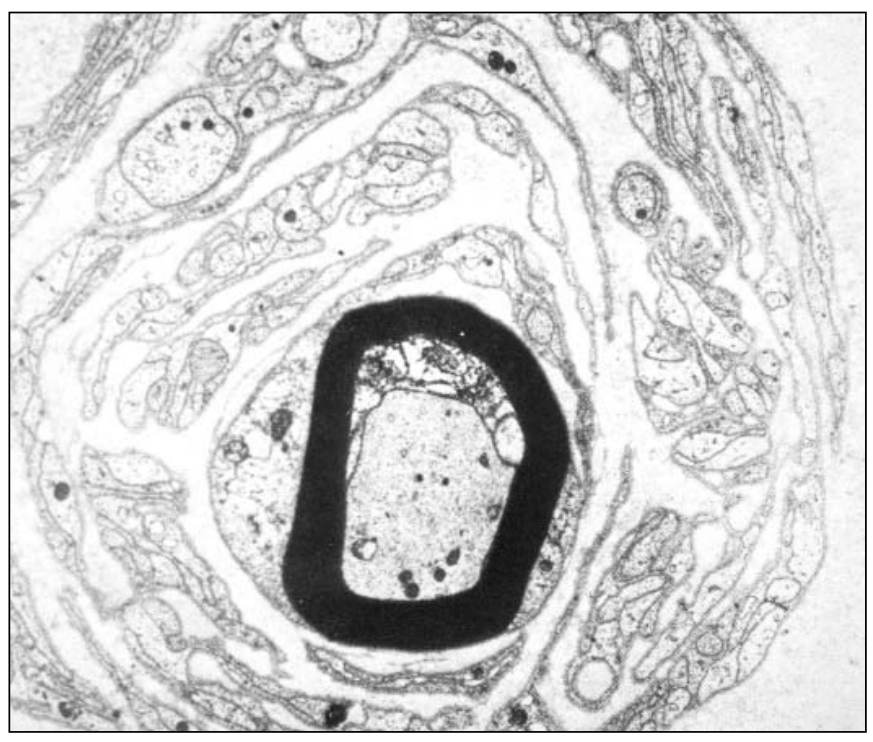

Figure 3: Onion bulb formation. Electron micrograph of sural nerve from an individual with CMT $1 A$ showing characteristic concentric Schwann cell cytoplasmic processes surrounding a myelinated axon.

are less prominent, with progressive replacement of the endoneurial space by collagen. ${ }^{40}$

Morphometric studies reveal a reduction in myelinated fibre density. ${ }^{43,58,61}$ This reduction correlates with clinical severity. ${ }^{40}$ The size distribution of myelinated fibres is altered. Early in life there is a modest loss of small fibres ${ }^{57}$ with a more prominent reduction in large fibres occurring later. ${ }^{43,58}$ Unmyelinated fibres are normal in number. ${ }^{58,62}$

Transverse sections and teased fibre studies reveal demyelination and remyelination involving some fibres, and areas of thin myelin are frequently observed. ${ }^{43,58}$ Segmental demyelination is most active before age five, slowing thereafter. ${ }^{63}$ Despite frequent areas of myelin remodeling, the mean $\mathrm{G}$ ratio (axon diameter:total fibre diameter) is decreased in young patients with CMT $1 \mathrm{~A},{ }^{60}$ becoming increased later in life. ${ }^{40}$ Although axonal atrophy has been suggested as a basis for the initial changes, ${ }^{64,65}$ it now seems likely that these abnormalities of myelin thickness reflect a state of hypermyelination. ${ }^{35,60}$

\section{CMT 1B}

\section{A) Clinical}

The less common $\mathrm{P}_{0}$ protein related neuropathies vary from the severe DSS and $\mathrm{CH}$ phenotypes to CMT $1 \mathrm{~B}$, which clinically is often indistinguishable from CMT 1A. Multiple $\mathrm{P}_{0}$ protein mutations have been detected and the site of the mutation and its consequent effect on $\mathrm{P}_{0}$ function does correlate with disease severity. ${ }^{37} \mathrm{CMT} 1 \mathrm{~B}$ will vary from a mild neuropathy, as is often seen in CMT 1A, to a condition that approaches the severity of DSS. ${ }^{66}$

\section{B) Electrophysiology}

The electrophysiologic findings in CMT 1B are less welldocumented as large groups of patients are not available for study. Limited information suggests that conduction abnormalities may be more severe than in CMT 1A. Bird ${ }^{67}$ described the findings in the original CMT 1B family followed over a 20-year period. Mean motor NCV was in the $9-11 \mathrm{~m} / \mathrm{s}$ range and lower limb motor responses were frequently unobtainable. Similarly low velocities were described in the original family with Roussy-Lévy syndrome, shown to possess a $\mathrm{P}_{0}$ mutation. All upper limb motor NCVs in this family were under $16 \mathrm{~m} / \mathrm{s}^{68}$ Interpretation of reported electrophysiologic abnormalities in patients with $\mathrm{P}_{0}$ mutations is complicated by the variable clinical phenotype, which includes individuals with DSS and $\mathrm{CH}$; very slow $\mathrm{NCV}$ in patients reported as having CMT 1B may reflect overlap with the DSS and $\mathrm{CH}$ phenotypes.

\section{C) Pathology}

Similar to electrophysiology, the pathology of CMT 1B has not been described in as much detail as CMT 1A. Bird ${ }^{67}$ reported the pathologic findings in CMT 1B patients with the C270A $\mathrm{P}_{0}$ transversion. Sural nerve biopsy changes were similar to those described for CMT 1A. A few fibres with focal myelin reduplication (tomaculae) were found in one patient. Myelin thickness was variably increased or decreased. One patient underwent autopsy, revealing degeneration of the dorsal columns (fasciculus gracilis) and chromatolysis and loss of some anterior horn cells. Plante-Bordeneuve ${ }^{68}$ described sural nerve biopsy findings in three patients with the Roussy-Lévy syndrome due to a $\mathrm{P}_{0}$ Asn131Lys (substitution of lysine for asparagine at the 131 position) point mutation. Focal myelin reduplication was present in all patients to some degree. Also in contrast to CMT 1A, onion bulbs were absent in two patients. Gabreels-Festen ${ }^{69}$ identified two contrasting patterns of pathology in patients with $\mathrm{P}_{0}$ mutations. Among seven patients with varying mutations, four demonstrated uncompacted myelin, typically involving the innermost layers of the myelin sheath, and widening of the major dense line. Onion bulbs were prominent in this group. In contrast, three patients showed normal compact myelin but frequent focal myelin reduplication. The mechanism of reduplication is unclear; however, the changes in compact myelin are of interest, given the known role of $\mathrm{P}_{0}$ as a homophilic myelin adhesion molecule. ${ }^{70}$

\section{Roussy-Lévy syndrome}

The original description by Roussy and Lévy was a large kindred with typical clinical features of CMT, autosomal dominant inheritance and associated essential tremor. ${ }^{71}$ Later descriptions of HMSN I included Roussy-Lévy syndrome patients under that general classification, as the clinical and electrophysiologic features of the neuropathy component resembled HMSN I. ${ }^{5}$ It has been hypothesized that the genes for the neuropathy and essential tremor are closely linked and in some kindreds may be concurrently abnormal. Modern molecular information has improved our understanding of the tremor component of CMT. Roussy-Lévy syndrome is not due to a single genetic defect. A subset of CMT 1A patients with the chromosome 17p11.2-12 duplication will have a Roussy-Lévy syndrome pattern, ${ }^{40}$ but the original Roussy and Lévy family has a missense point mutation in the $\mathrm{P}_{0}$ protein gene. ${ }^{68}$ Tremor has also been reported with CMT X. ${ }^{72}$ The coincidental expression of essential tremor and CMT may not have anything to do with a specific gene abnormality, though a separate genetic defect 
producing essential tremor may be present in some kindreds. In many patients, the tremor may be merely a clinical manifestation of the neuropathy, as in chronic inflammatory demyelinating polyradiculoneuropathy and other acquired demyelinating neuropathies an essential-like tremor may develop. ${ }^{73,74}$ The presence of tremor is not currently a helpful sign in distinguishing CMT genotype.

\section{CMT 2}

\section{A) Clinical}

Patients with a typical dominantly inherited CMT phenotype who have electrophysiologic features of a primarily axonal disorder have CMT 2. Typical patients with CMT 2 have a similar clinical appearance to patients with CMT 1, though some differences have been detected. The CMT 2 patients tend to present with symptoms later in life than CMT 1 and the degree of atrophy and weakness in distal lower extremity muscles may be greater with relatively less weakness of intrinsic hand muscles. ${ }^{8}$ Nerve hypertrophy is absent. Similar to CMT 1, multiple genetic abnormalities have been described producing the CMT 2 phenotype but less is known about the gene products of loci identified to date. Families with CMT 2 have been linked to chromosome 1p35-p36 (CMT 2A), ${ }^{75,76} 3 \mathrm{q} 13$-q22 (CMT 2B), ${ }^{77,78} 7$ p14 (CMT 2D) ${ }^{79}$ and 8p21 (CMT 2E). ${ }^{80}$ The CMT 2C kindred has not yet been linked to a chromosomal region. The CMT 2E trait has been associated with a mutation in the neurofilament-light gene (NF-L), which likely leads to impairment of axonal transport and axonal diameter. Some CMT 2 families have special features, such as mutilating ulcers (CMT 2B), ${ }^{78}$ diaphragm and vocal cord paralysis which can lead to early death (CMT 2C) ${ }^{81}$ and greater weakness of hands than legs (CMT 2D). ${ }^{79}$ However, most CMT 2 families have typical CMT features and would be difficult to distinguish from CMT 1 based on clinical assessment alone without electrophysiologic information.

Myelin protein gene abnormalities can occasionally lead to a disorder that appears primarily axonal. In CMT 1 axonal neurofilament numbers are reduced out of proportion to myelin sheath thickness ${ }^{65}$ and Schwann cells may influence axonal repair through nerve growth factor support ${ }^{82}$ and other influences on cytoskeletal elements. ${ }^{23}$ The CMT 2 phenotype has been associated with mutations of myelin proteins such as $\mathrm{P}_{0}$ gene mutations. ${ }^{83-85}$ A Thr124Met mutation on myelin $\mathrm{P}_{0}$ may be particularly important as multiple families with this mutation have shown features of CMT $2 .{ }^{85}$ As well, CMT X electrophysiology and nerve pathology can have the appearance of an axonal process.

\section{B) Electrophysiology}

The EMG findings in CMT 2 are not distinctive and reflect an axonal sensorimotor polyneuropathy. CMT 2 is differentiated from distal spinal muscular atrophy (which it may resemble clinically) by the presence of sensory conduction abnormalities. ${ }^{86}$ Compound muscle action potentials are reduced in amplitude or unobtainable but conduction velocities are normal or only mildly reduced. ${ }^{8}$ In Dyck's ${ }^{8}$ series, motor NCV were within normal limits in most affected subjects, although slightly reduced as a group when compared to unaffected family members. Harding and Thomas ${ }^{11}$ noted that CMT 2 motor NCV exceeded $38 \mathrm{~m} / \mathrm{s}$. Sensory nerve action potentials are reduced or unobtainable. ${ }^{8}$ It should be noted that these changes are nonspecific, and may also be seen in patients with CMT X and CMT 4. Electrodiagnostic studies are thus mainly useful in excluding CMT 1.

CMT 2 kindreds may include individuals with rather low $\mathrm{NCV}$, despite most affected subjects having velocities in the normal range. Timmerman ${ }^{75}$ reported one individual in an otherwise typical CMT 2 family with motor conduction velocities in the $25 \mathrm{~m} / \mathrm{s}$ range. Patients with "intermediate" conduction velocities (i.e. $30-40 \mathrm{~m} / \mathrm{s}$ ) may be identified, in whom assignment to CMT 1 versus CMT 2 would be difficult in isolation. Possibilities include CMT $X^{87-90}$ and CMT 2. Electrodiagnostic study of family members will usually clarify this.

Needle examination demonstrates evidence of chronic deand reinnervation. Motor unit recruitment is reduced, with increased motor unit duration and amplitude. Motor units may appear polyphasic but are often of simple configuration and high amplitude given the indolent nature of the process. Fibrillations are often present in distal muscles.

\section{C) Pathology}

These disorders are less well-characterized than CMT 1 and the pathology is less distinctive. Myelinated fibre density is reduced, especially distally. ${ }^{62}$ The size distribution may be altered, with a relative reduction in large fibres. ${ }^{58,62}$ Small myelinated fibres are normal or increased in number relative to controls, particularly in proximal nerve segments, due in part to the presence of regenerating axons. ${ }^{58,62}$ Axonal atrophy is present. ${ }^{91}$ Morphometric studies have shown a shift in the small fibre peak to smaller diameters than controls, in keeping with axonal atrophy, regeneration or both. Endoneurial area is normal or slightly increased. ${ }^{58}$ Occasional small onion bulbs are present. Teased fibres may show evidence of myelin re-modeling.

With the sub-classification of CMT 2 based on genetic markers, more distinctive pathologic changes may eventually be identified. In a German kindred with CMT 2 associated with cardiomyopathy, sural nerve biopsy demonstrated focal axonal swellings containing accumulations of neurofilaments. ${ }^{92}$ This family appeared clinically and genetically distinct from giant axonal neuropathy, in which similar pathology is seen.

\section{CMT X}

\section{A) Clinical}

Typical CMT with more severe expression in males than females characterizes CMT X. The age of onset of symptoms is usually younger in affected males than in female heterozygous expressors. At least half of affected males have recognized symptoms in the first two decades, whereas less than a third of females note symptoms by this age. ${ }^{89}$ Males have significantly greater muscle wasting, loss of reflexes and disability. However, there is overlap in the severity of manifestations between males and females of different kindreds. The intra-family comparison is an important yardstick, which may raise consideration of $\mathrm{X}$ linked inheritance. Variable expression of CMT within families is common in CMT 1 and 2 and without large kindreds it may not 


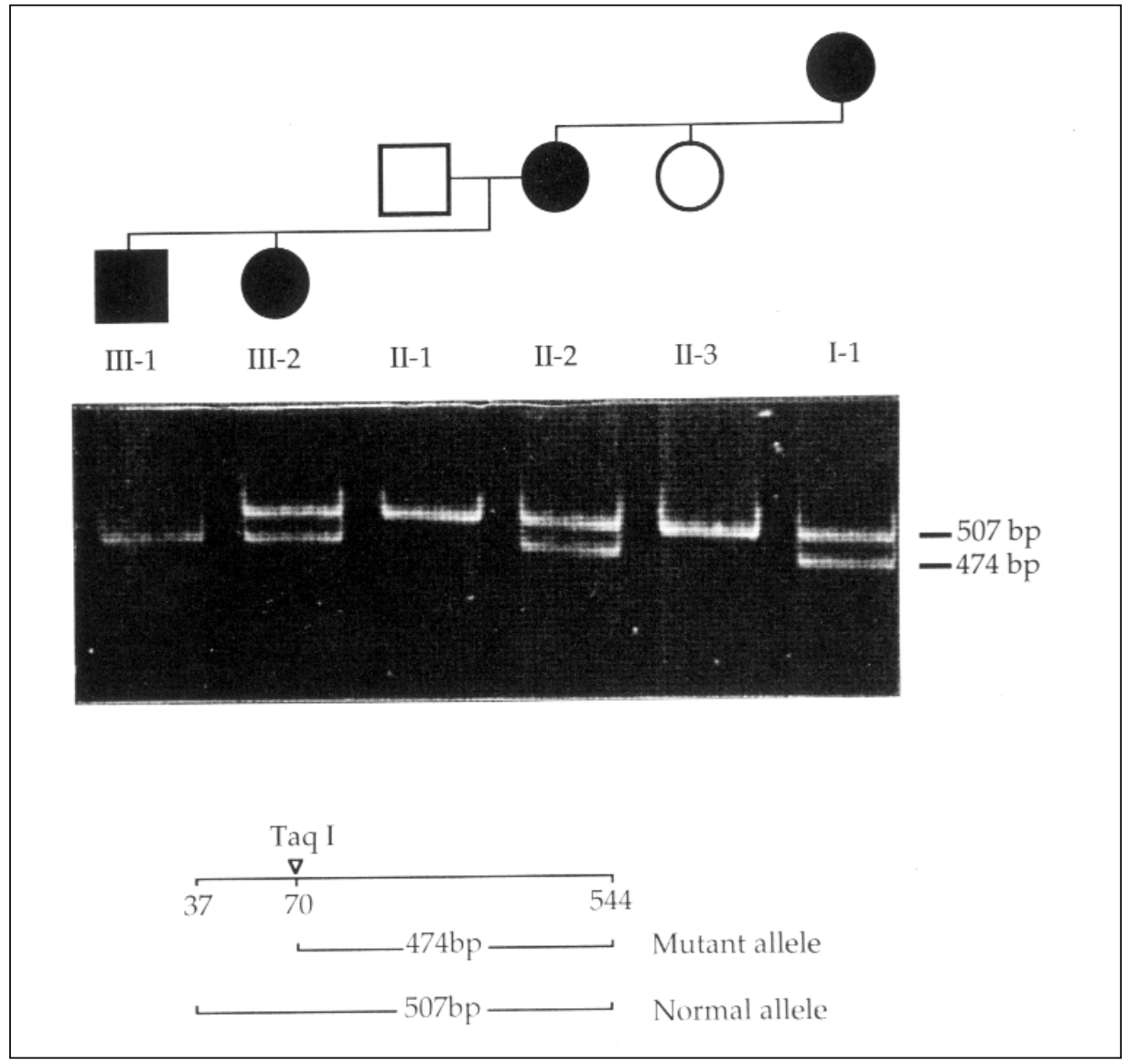

Figure 4: CMTX. The pedigree in the top panel demonstrates maternal transmission of a mutant connexin 32 gene to a son and daughter. This family was shown to have a codon 3 mutation in the connexin 32 gene by polymerase chain reaction amplification followed by TaqI restriction analysis. The $G \rightarrow C$ mutation in codon 3 creates a novel TaqI restriction site. The mutant allele was detected in patients III-1, III-2, II-2 and I-1 (middle panel) by the presence of a 474 base pair fragment (lower panel). [From Gupta S, Benstead T, Neumann P, Guernsey D. A point mutation in codon 3 of connexin32 is associated with X-linked Charcot-Marie-Tooth neuropathy. Hum Mutat 1996;8(4):375-376. Reprinted by permission of Wiley-Liss, Inc., a subsidiary of John Wiley \& Sons, Inc.]

always be obvious that the inheritance is X-linked. Absence of male-to-male transmission of a dominantly inherited CMT trait should always raise the consideration of CMT X. ${ }^{93}$ The pedigree in Figure 4 demonstrates the inheritance of a maternal mutant Cx32 allele by a son and daughter.

CMT X is associated with point mutations in the gap-junction protein Cx32 located at $\mathrm{Xq} 13-22 .{ }^{94}$ The disorder is almost always inherited dominantly. A de novo $\mathrm{Cx} 32$ mutation has been described and this should be considered in seemingly sporadic CMT cases. ${ }^{95}$ Recessive inheritance has been reported, ${ }^{96}$ though recessive inheritance should not be assumed without careful clinical and electrophysiological assessment of female carriers, due to the often-mild expression. Currently, around 160 mutations have been reported with some phenotypic variability between families represented by different mutations. There is some correlation between the location of the mutation on the Cx32 gene and the character of the neuropathy. Missense mutations within regions of the protein less critical to $\mathrm{Cx} 32$ function lead to a milder neuropathy. Nonsense mutations are associated with earlier onset of disease expression and more severe neuropathy ${ }^{89,90}$ About $10 \%$ of CMT patients have Xlinked inheritance, making CMT $\mathrm{X}$ the second most common form of $\mathrm{CMT}^{97}$ after CMT $1 \mathrm{~A}$.

The $\mathrm{Cx} 32$ defect has produced clinical manifestations restricted to the peripheral nervous system in the majority of patients reported to date, despite the presence of $\mathrm{Cx} 32$ in oligodendrocytes. Mice without the Cx32 gene develop a peripheral neuropathy but central myelinated fibres are unaffected. $^{98}$ Asymptomatic electrophysiological abnormalities within the central nervous system have been reported in some patients ${ }^{99,100}$ but a comprehensive assessment of CNS function is not available for the majority of reported CMT X patients. It seems unlikely that the CNS consequences of this gene defect will be significant given the experience with the disorder to date.

\section{B) Electrophysiology}

Motor conduction slowing is typical of CMT X but this entity has caused confusion in part due to the common occurrence of 
intermediate velocities falling between the ranges typical for CMT 1 and CMT 2. ${ }^{87,89,90,101}$ Men generally show slower velocities than women. ${ }^{87,89,90}$ Interestingly, there is some disagreement about which group displays the "intermediate" velocities. For example, Nicholson ${ }^{87}$ described marked slowing in affected males and intermediate velocities in females, while $\mathrm{Hahn}^{90}$ described intermediate velocities in males with borderline normal values in women. Distal motor latencies are typically prolonged. Compound muscle action potential amplitudes are often reduced. Sensory potentials are small or unobtainable; sensory conduction changes probably show less difference between affected males and females than do motor changes. $^{90}$ Needle examination shows evidence of chronic denervation and reinnervation, most marked in distal muscles.

Recent attention has focused on the occurrence of nonuniform conduction slowing in CMT X. This is manifested as heterogeneous slowing comparing multiple nerves and by the presence of dispersion. ${ }^{102,103}$ Sural nerve biopsy in these cases has shown thin myelin and onion bulbs, in keeping with a chronic demyelinating process. However, nonuniform conduction slowing is not invariably found. ${ }^{90}$

The electrophysiologic features of CMT X are more likely to suggest an axonal disorder than one characterized by primary demyelination. However, some patients will have strong indicators of demyelination, such as slow conduction velocities and prolonged distal latencies. Differences in electrophysiologic findings of various studies have made it difficult to categorize CMT X based on usual parameters. The primary process leading to neuropathy in CMT $X$ will be difficult to define using electrophysiologic criteria alone.

\section{C) Pathology}

Typical nerve biopsy findings include a reduction in myelinated fibre density, ${ }^{89,90}$ thinly myelinated fibres, many regenerating clusters, and low-grade axonal degeneration. ${ }^{90,104}$ In the largest series, Hahn ${ }^{90}$ described sural, superficial peroneal or deep peroneal (motor) biopsy changes in seven unrelated male patients with a variety of $\mathrm{Cx} 32$ mutations. There was mild to moderate loss of myelinated fibres, which appeared age-related. Frequent regenerating clusters and myelin remodeling were present. Onion bulbs were absent. Teased fibre studies revealed prominent paranodal demyelination with little segmental demyelination or active axonal degeneration. Electron microscopy revealed widening of the periaxonal space, SchmidtLanterman incisures and adaxonal Schwann cell cytoplasm. Axonal cytoskeletal changes were present with increased neurofilament content.

There has been disagreement as to whether CMT X is a primary demyelinating or axonal neuropathy. Previous reports have emphasized the axonal changes, ${ }^{75,89}$ while others have described demyelination. ${ }^{102,103}$ This issue has not been completely resolved. However, currently available evidence suggests that while the most prominent, consistent changes are axonal, some degree of demyelination is also present. Increasing evidence, including that from animal models ${ }^{105}$ suggests that Cx32 is important in Schwann cell-axon interactions and it may be most accurate to categorize this disorder as a disease of Schwann cells that leads to axonal loss and demyelination. The variability in reported findings may relate to the large number of
Cx32 mutations described and to varying disease expression according to the specific mutation and resulting alteration in protein function.

\section{HEREDITARY NEUROPATHY WITH LIABILITY TO PRESSURE PALSIES}

\section{A) Clinical}

Hereditary neuropathy with liability to pressure palsies is a familial disorder with a predisposition to develop compression and entrapment neuropathies. The condition has been recognized for almost 50 years $^{106}$ with clear descriptions, in the premolecular era of the clinical, electrophysiological and morphological features. ${ }^{107}$ The disorder is dominantly inherited and most kindreds demonstrate a deletion of the 17p11.2-12 region containing the PMP22 gene. ${ }^{108}$ In one group of HNPP families the prevalence of the 17p11.2-12 deletion was $68 \%$. Affected family members of symptomatic patients are often asymptomatic or minimally symptomatic. Determining the inheritance of patients with suspected HNPP often requires detailed assessment of family members, as presence of the disorder may not be appreciated by affected family members. ${ }^{107}$ The family history may also be truly negative due to rare sporadic cases from new mutations. ${ }^{109}$ In some nondeletion families a loss of function point mutation in the PMP22 gene will produce the HNPP phenotype. ${ }^{29-31}$

Symptomatic HNPP patients may only become aware of their problem after developing a focal neuropathy from an episode of nerve compression or traction. From the history, the compressive insult is often seemingly minor. Common sites for traumatic or compressive nerve lesions are the median nerve at the wrist, ulnar nerve at the elbow, radial nerve at the humeral groove and peroneal nerve at the knee. However, HNPP patients will also develop lesions at less common sites of compression if the provocative factor is appropriate. The lesions usually recover in a few weeks to months, similar to most sporadic mild compression neuropathies. Without a provoking episode the patient is often not aware of the problem. An exception is carpal tunnel syndrome, which will often become symptomatic without any definite provoking event. Family members of patients with HNPP may have a history of carpal tunnel syndrome as the only clue of their involvement.

The prevalence of HNPP was 16/100,000 in one population ${ }^{110}$ but epidemiological data are sparse in this disorder. In the population studied, it was felt that the prevalence might have been underestimated due to HNPP's insidious nature and the failure of many patients to seek attention for typical symptoms. Variability in the phenotypic expression may also contribute to under-recognition, as patients without typical syndromes may not be tested appropriately. In a group of patients with multifocal neuropathies, a PMP22 deletion was found in patients with a typical presentation and in some with atypical features. ${ }^{111}$ Atypical presentation of HNPP includes episodes of acute brachial neuropathy ${ }^{107,111-113}$ and polyneuropathy. ${ }^{112,114}$ The brachial plexus lesions of HNPP are painless, as opposed to inherited recurrent brachial neuropathy (hereditary neuralgic amyotrophy), which is typically heralded by severe pain and unaccompanied by nonbrachial conduction abnormalities. Patients with hereditary neuralgic amyotrophy do not have a chromosome 17p11.2-12 deletion, ${ }^{115}$ but a locus has been 
identified in the chromosome $17 \mathrm{q} 24-\mathrm{q} 25$ region. ${ }^{116,117}$ HNPP can produce a more diffuse polyneuropathy, sometimes severe and fulminant ${ }^{118,119}$ but, in others, without a clear stepwise progression. Patients with polyneuropathy may be older, perhaps due to the coalescence of many focal lesions in distal nerves producing a diffuse symmetrical appearance. ${ }^{114}$

\section{B) Electrophysiology}

The electrodiagnostic picture in HNPP reflects single or multiple focal compressive neuropathies at common entrapment sites. Focal conduction abnormalities are no different from those seen in entrapment neuropathies unassociated with HNPP. Nerve conduction studies demonstrate focal slowing, temporal dispersion and conduction block, alone or in combination. ${ }^{107,120,121}$ With more severe or chronic focal lesions, axonal degeneration may develop, resulting in a reduced compound muscle action potential amplitude stimulating distal to the site of injury and evidence of denervation on needle examination. When axon loss is the major finding, localization of the site of nerve injury may not be possible.

These focal changes are often multiple and may be asymptomatic. ${ }^{122}$ The disorder is often suspected through detection of multiple asymptomatic abnormalities at sites of common compression, found during evaluation of a single symptomatic lesion. With or without associated symptoms, conduction block may persist over a period of years. ${ }^{120}$ The prevalence of conduction block in HNPP is unclear, as the frequency in published reports varies according to the definition of block used. ${ }^{121}$

Typically, focal lesions occur against a background of diffuse polyneuropathy. These generalized changes are characterized by diffuse slowing of sensory $\mathrm{NCV},{ }^{107,114,123}$ prolonged distal motor latencies ${ }^{114,122,123}$ and prolonged $\mathrm{F}$ latencies. ${ }^{114,123}$ Evidence of a focal median neuropathy at the wrist is particularly common ${ }^{114,123}$ but the characteristic prolongation of distal motor latencies is evident even if the median nerve is excluded. ${ }^{123}$ This distal slowing is out of proportion to slowing in proximal segments, as illustrated by a low terminal latency index. ${ }^{123}$ Notably, forelimb motor NCV is relatively spared. ${ }^{114,122,123}$ Andersson $^{123}$ found reduced motor NCV in $31 \%$ of HNPP nerves studied but the overall mean motor velocity was normal. This contrasted with control groups with CIDP and diabetes, in whom motor slowing was significantly more frequent.

Given the potential difficulty in recognizing this pattern in patients in whom HNPP is not suspected, diagnostic criteria have been proposed. Verhagen ${ }^{124}$ has proposed a formula combining changes in peroneal and ulnar motor NCV with the peroneal distal motor latency. Gouider ${ }^{125}$ found that HNPP was likely when the following criteria are met: bilateral prolongation of median distal motor latencies, reduced median sensory NCV in the palm to wrist segment and either a prolonged peroneal distal motor latency or reduced peroneal motor NCV.

In patients with HNPP, diffuse conduction abnormalities are more prominent in cases due to PMP22 point mutations or insertions than in those with the more common 17p11.2-12 deletion. Lenssen ${ }^{29}$ described six families with a heterozygous insertion of six nucleotides at nt276-281 of the PMP22 gene, resulting in a frame shift. Motor NCVs were slowed in the CMT 1 range and sural sensory responses were usually absent. The authors suggested these changes reflect not just reduced PMP22 expression but the additional detrimental effect of a truncated protein on Schwann cell function.

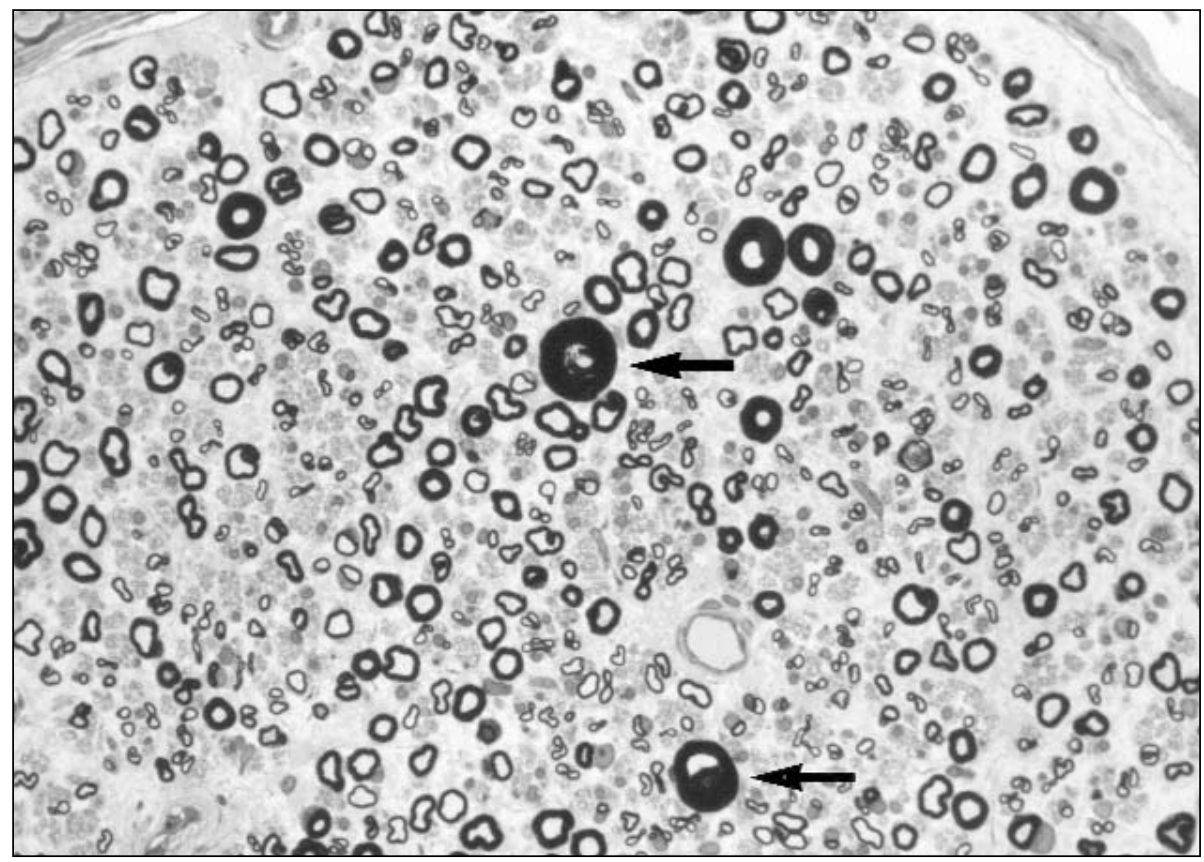

Figure 5: Hereditary neuropathy with liability to pressure palsies. Semithin section of sural nerve demonstrating several fibres within a fascicle surrounded by focal reduplication of the myelin sheath (arrows). (Methylene blue, 400X) 
Overall, the electrophysiologic changes in HNPP are consistent with a background, predominantly sensory demyelinating polyneuropathy, with distal accentuation. ${ }^{122,123}$

\section{C) Pathology}

Most reports describe sural nerve biopsy findings. Focal thickening of the myelin sheath is the most distinctive finding (Figure 5). These were first described by Behse, ${ }^{107}$ who called them "sausages". They have also been called "tomaculae". ${ }^{126}$ The tomaculae consist of redundant folds or loops of the myelin sheath, resulting in thickened segments best appreciated in semithin sections and teased fibre preparations. ${ }^{107,126,127}$ The redundant loops are continuous with internodal myelin. ${ }^{127}$ Although ultrastructural studies usually demonstrate normal myelin layering, uncompacted lamellae involving the innermost layers of the myelin sheath have been described. ${ }^{127}$ Focal myelin reduplication is not specific to HNPP, and has also been described in CMT 1A ${ }^{40} \mathrm{CMT} 1 \mathrm{~B}$, and CMT 4B (see below). HNPP pathologic changes also include segmental demyelination and remyelination. ${ }^{107,127}$ Axonal diameter is reduced adjacent to tomaculae. $^{128}$

\section{DeJERINe-SotTas Syndrome}

Dejerine-Sottas syndrome is a rare, severe neuropathy with onset very early in life and loss of motor function such as walking at a young age. It is often associated with scoliosis and nerve hypertrophy is usually easily detectable. Early reports suggested recessive inheritance but modern molecular studies have shown most DSS patients have sporadic point mutations in the genes for $\mathrm{P}_{0}$ protein, ${ }^{37,129,130} \mathrm{PMP} 22^{131,132}$ or EGR2. ${ }^{27} \mathrm{~A}$ phenotype more severe than CMT 1, suggestive of DSS, can also occur with homozygous expression of CMT 1A or CMT 1B. This was described prior to linkage studies by Killian ${ }^{133}$ in 1979 and later once the gene abnormalities were recognized. ${ }^{36,134}$ Homozygous 17p11.2-12 duplication patients have four copies of the PMP22 gene resulting in greater over-expression of the gene than occurs in CMT 1A, where three copies of the gene are present. These patients have more severe neuropathy than their parents and some have NCV less than $10 \mathrm{~m} / \mathrm{s}$ but the Killian patients did not exhibit the severity of neuropathy typical of the DSS patients reported by Dyck, in whom the ability to walk independently was lost in childhood.

The electrodiagnostic characteristics of DSS were described by Benstead. ${ }^{135}$ This study predated identification of the underlying genetic abnormalities outlined above, and diagnosis was based on clinical criteria. Eleven unrelated patients with a mean age of 17 years were reported. Nerve conduction abnormalities were qualitatively similar but more severe than those of a control group with CMT 1. Upper limb motor amplitudes were severely reduced, typically to $10 \%$ of the lower limit of normal. Motor NCV was invariably less than $6 \mathrm{~m} / \mathrm{s}$, with uniform slowing comparing multiple nerves. Distal motor latencies were severely increased to 6-7 times normal values. Dispersion was sometimes noted with proximal stimulation, although in association with very low amplitude compound muscle action potentials. Sensory responses were almost always unrecordable. Similar severely reduced NCVs were noted by others. ${ }^{5,59}$

A recent statement of criteria for DSS (or HMSN III) has become very important, as evidence for the genetic heterogeneity for the disorder has appeared. It will not be possible to diagnose the disorder merely on the basis of a characteristic DNA abnormality, as several exist. ${ }^{136}$ Gabreels-Festen proposed the HMSN III (DSS) designation be reserved for patients with congenital or early childhood onset, $\mathrm{NCV}<7 \mathrm{~m} / \mathrm{s}$, virtual absence of myelin on biopsy and basal lamina onion bulbs.

\section{CONGENITAL HYPOMYELINATION NEUROPATHY}

Lyon $^{137}$ and others ${ }^{138-140}$ described a congenital hypomyelination neuropathy with features similar to DSS but possibly worse, in that some patients never walked, which is uncommon in descriptions of DSS. Infants with $\mathrm{CH}$ have severe hypotonia, weakness, respiratory and swallowing difficulty. Early reports of $\mathrm{CH}$ emphasized the virtual absence of myelin sheaths, with only multiple layers of basement membrane surrounding large axons and forming onion bulbs. ${ }^{140}$ The disorder was considered to either represent the severest end of the spectrum of patients with HMSN III or DSS or to be a separate genetic entity with complete failure of myelin production by Schwann cells. Mutations of the $\mathrm{P}_{0}$ protein $^{37}$ and EGR2 ${ }^{24}$ have been described in patients with $\mathrm{CH}$.

\section{CMT 4}

\section{A) Clinical}

The issue of recessive inheritance has confounded classification schemes in the past. Though usually referring to dominantly inherited neuropathies, the HMSN I and II designations have been used in patients with apparent recessive inheritance. ${ }^{11}$ Dejerine-Sottas syndrome was suspected to be usually recessively inherited based on early kinships. ${ }^{5}$ Molecular analysis has demonstrated spontaneous point mutations in disorders previously thought to be predominantly recessively inherited. ${ }^{131}$ Nevertheless, genetic loci have been identified through homozygosity mapping in kindreds with autosomal recessive CMT. The first locus mapped was in chromosome 8q13-q21.1 in four Tunisian families. ${ }^{141}$ The recessive demyelinating form of CMT has been designated CMT 4, with the 8q13-8q21.1 locus assigned CMT 4A. The CMT 4A patients demonstrated evidence of hypomyelination and basal lamina onion bulbs on nerve biopsy. Additional loci in other pedigrees include chromosome 11q23 (CMT 4B), ${ }^{142}$ 5q23-q33 (CMT 4C), ${ }^{143,144} 8 \mathrm{q} 24$ (CMT 4D) ${ }^{145}$ and 19q13.1-13.3 (CMT 4F). ${ }^{146}$ Two autosomal recessive forms of CMT with axonal features have been mapped to $1 \mathrm{q} 21.2-\mathrm{q} 21.3^{147}$ and $19 \mathrm{q} 13.3 .{ }^{148}$ The autosomal recessive axonal neuropathies are sometimes designated AR-CMT 2. The recessive neuropathies, in general, have been severe and have arisen from a broad range of European and non-European communities. The 8q24 locus has associated deafness. ${ }^{145}$

\section{B) Electrophysiology}

Electrophysiological findings reflect the severe nature of these neuropathies. Quattrone ${ }^{149}$ described the electrophysiology in 10 patients from a family now considered to have CMT 4B. Affected individuals had a severe demyelinating neuropathy approaching the degree of changes seen in DSS. Motor NCVs in the upper 
limbs were in the $15-17 \mathrm{~m} / \mathrm{s}$ range in children, with unrecordable motor responses in older patients. Sensory responses were usually absent. Compound muscle action potentials were low in amplitude and dispersed. Brain stem auditory evoked potentials revealed prolonged peak 1-3 interpeak latencies.

\section{C) Pathology}

Nerve biopsy in Quattrone's series demonstrated severe myelinated fibre loss, maximal in older patients. ${ }^{149}$ Most fibres showed focal myelin reduplication ("focal folding of the myelin sheath"). Thin myelin was present surrounding fibres without reduplication. Occasional onion bulbs were noted. On teased fibre studies, the areas of focal folding were felt to differ from classic tomaculae by virtue of their marked nodular irregularity. These changes were confirmed on electron microscopy.

Focal myelin reduplication has frequently been reported in association with autosomal recessive CMT. ${ }^{150-155}$ Most patients have had a neuropathy of congenital or childhood onset with severe progressive disability and a shortened life span, overlapping with DSS. Some authors have noted a similar morphology to the tomaculae of HNPP ${ }^{150,152}$ while others have emphasized morphologic differences. ${ }^{149,154}$

Limited information is available about other CMT 4 subtypes. Ben Othmane ${ }^{141}$ described the conduction slowing, severe hypomyelination and basal lamina onion bulbs in patients with CMT 4A. Kessali ${ }^{156}$ noted typical onion bulbs in patients with CMT 4C. Characteristic morphologic features of nerve biopsy specimens have been associated with some recessive loci but the morphologic abnormalities are not specific to any single phenotype. For instance, the 11q23 locus (CMT 4B) abnormality produces a severe neuropathy with focally folded myelin. ${ }^{149}$ However, focally folded myelin sheaths have also been associated with a heterozygous dominant point mutation on the myelin $\mathrm{P}_{0}$ gene. ${ }^{157,158}$ The gene products associated with several CMT 4 chromosomal loci identified are not known, though some candidate gene products have been identified. ${ }^{159}$

\section{CONCLUSION}

Advances in understanding the many faces of CMT have been rapid, fueled by the progress in correlating clinical presentation with molecular defect. Some of the CMT phenotypic variability clinicians detect can be explained by abnormalities in different target genes, or differences in gene target dosing. There is more to learn, as there is striking phenotypic variability within and between families with identical gene defects, as seen in CMT 1A. Identification of gene product abnormalities is the first step toward developing therapies that will effectively treat CMT. Already the knowledge available is useful for genetic counseling and aiding prognosis. For the commoner forms of CMT, such as CMT 1, CMT X and HNPP, genetic tests are readily available to the clinician. However, accurate diagnosis and management of this diverse group of peripheral neuropathies continues to demand skill and experience in the clinical and electrophysiological evaluation of neuromuscular disease.

\section{REFERENCES}

1. Skre H. Genetic and clinical aspects of Charcot-Marie-Tooth's disease. Clin Genet 1974;6(2):98-118.
2. Combarros O, Calleja J, Polo JM, Berciano J. Prevalence of hereditary motor and sensory neuropathy in Cantabria. Acta Neurol Scand 1987;75(1):9-12.

3. Holmberg BH. Charcot-Marie-Tooth disease in northern Sweden: an epidemiological and clinical study. Acta Neurol Scand 1993;87(5):416-422.

4. Lupski JR, Chance PF, Garcia CA. Inherited primary peripheral neuropathies. Molecular genetics and clinical implications of CMT 1A and HNPP. JAMA 1993;270(19):2326-2330.

5. Dyck PJ, Lambert EH. Lower motor and primary sensory neuron diseases with peroneal muscular atrophy. I. Neurologic, genetic, and electrophysiologic findings in hereditary polyneuropathies. Arch Neurol 1968;18(6):603-618.

6. Coutinho P, Barros J, Zemmouri R, et al. Clinical heterogeneity of autosomal recessive spastic paraplegias: analysis of 106 patients in 46 families. Arch Neurol 1999;56(8):943-949.

7. Schelhaas HJ, Hulst MV, Ippel E, Prevo RL, Hageman G. Early onset cerebellar ataxia with retained tendon reflexes: foot deformity in a first grade family member. Clin Neurol Neurosurg 1999;101(4):253-255.

8. Dyck PJ, Lambert EH. Lower motor and primary sensory neuron diseases with peroneal muscular atrophy. II. Neurologic, genetic, and electrophysiologic findings in various neuronal degenerations. Arch Neurol 1968;18(6):619-625.

9. Gilliatt RW, Thomas PK. Extreme slowing of nerve conduction in peroneal muscular atrophy. Ann Phys Med 1957;15:104-106.

10. Lambert EH. Clinical Examinations in Neurology. Philadelphia: W.B. Saunders, 1956:287-317.

11. Harding AE, Thomas PK. The clinical features of hereditary motor and sensory neuropathy types I and II. Brain 1980;103(2):259-280.

12. Dyck PJ, Oviatt KF, Lambert EH. Intensive evaluation of referred unclassified neuropathies yields improved diagnosis. Ann Neurol 1981;10(3):222-226.

13. Harding AE, Thomas PK. Autosomal recessive forms of hereditary motor and sensory neuropathy. J Neurol Neurosurg Psychiatry 1980;43(8):669-678.

14. Bird TD, Ott J, Giblett ER. Evidence for linkage of Charcot-MarieTooth neuropathy to the Duffy locus on chromosome 1 . Am J Hum Genet 1982;34(3):388-394.

15. Stebbins NB, Conneally PM. Linkage of dominantly inherited Charcot-Marie-Tooth neuropathy to the Duffy locus in an Indiana family. Am J Hum Genet 1982;34:195A.

16. Vance JM, Nicholson GA, Yamaoka LH, et al. Linkage of CharcotMarie-Tooth neuropathy type 1a to chromosome 17. Exp Neurol 1989;104(2):186-189.

17. Chance PF, Bird TD, O'Connell P, et al. Genetic linkage and heterogeneity in type I Charcot-Marie-Tooth disease (hereditary motor and sensory neuropathy type I). Am J Hum Genet 1990;47(6):915-925.

18. Hahn AF, Brown WF, Koopman WJ, Feasby TE. X-linked dominant hereditary motor and sensory neuropathy. Brain 1990;113(Pt 5):1511-1525.

19. Krajewski KM, Lewis RA, Fuerst DR, et al. Neurological dysfunction and axonal degeneration in Charcot-Marie-Tooth disease type 1A. Brain 2000;123(Pt 7):1516-1527.

20. Jetten AM, Suter U. The peripheral myelin protein 22 and epithelial membrane protein family. Prog Nucleic Acid Res Mol Biol 2000;64:97-129.

21. Shapiro L, Doyle JP, Hensley P, Colman DR, Hendrickson WA. Crystal structure of the extracellular domain from $\mathrm{P}_{0}$, the major structural protein of peripheral nerve myelin. Neuron 1996; 17(3):435-449.

22. Scherer SS, Deschenes SM, Xu YT, et al. Connexin32 is a myelinrelated protein in the PNS and CNS. J Neurosci 1995;15(12): 8281-8294.

23. Sahenk Z, Chen L, Mendell JR. Effects of PMP22 duplication and deletions on the axonal cytoskeleton. Ann Neurol 1999;45(1): 16-24.

24. Warner LE, Mancias P, Butler IJ, et al. Mutations in the early growth response 2 (EGR2) gene are associated with hereditary myelinopathies. Nat Genet 1998;18:382-384.

25. Kamholz J, Awatramani R, et al. Regulation of myelin-specific 
gene expression. Relevance to CMT 1. Ann N Y Acad Sci 1999;883:91-108.

26. Bellone E, Di Maria E, Soriani S, et al. A novel mutation (D305V) in the early growth response 2 gene is associated with severe Charcot-Marie-Tooth type 1 disease. Hum Mutat 1999;14(4): 353-354.

27. Timmerman V, De Jonghe P, Ceuterick C, et al. Novel missense mutation in the early growth response 2 gene associated with Dejerine-Sottas syndrome phenotype. Neurology 1999;52(9): 1827-1832.

28. Schenone A, Nobbio L, Mandich P, et al. Underexpression of messenger RNA for peripheral myelin protein 22 in hereditary neuropathy with liability to pressure palsies. Neurology 1997; 48:445-449.

29. Lenssen PP, Gabreels-Festen AA, Valentijn LJ, et al. Hereditary neuropathy with liability to pressure palsies. Phenotypic differences between patients with the common deletion and a PMP22 frame shift mutation. Brain 1998;121(Pt 8):1451-1458.

30. Nicholson GA, Valentijn LJ, Cherryson AK, et al. A frame shift mutation in the PMP22 gene in hereditary neuropathy with liability to pressure palsies [published erratum appears in Nat Genet 1994 May;7(1):113]. Nat Genet 1994;6(3):263-266.

31. Young P, Wiebusch H, Stogbauer F, et al. A novel frameshift mutation in PMP22 accounts for hereditary neuropathy with liability to pressure palsies. Neurology 1997;48(2):450-452.

32. Vallat JM, Sindou P, Preux PM, et al. Ultrastructural PMP22 expression in inherited demyelinating neuropathies. Ann Neurol 1996;39(6):813-817

33. Gabriel JM, Erne B, Pareyson D, et al. Gene dosage effects in hereditary peripheral neuropathy. Expression of peripheral myelin protein 22 in Charcot-Marie-Tooth disease type 1A and hereditary neuropathy with liability to pressure palsies nerve biopsies. Neurology 1997;49(6):1635-1640.

34. Yoshikawa H, Nishimura T, Nakatsuji Y, et al. Elevated expression of messenger RNA for peripheral myelin protein 22 in biopsied peripheral nerves of patients with Charcot-Marie-Tooth disease type 1A. Ann Neurol 1994;35(4):445-450.

35. Fabrizi GM, Simonati A, Morbin M, et al. Clinical and pathological correlations in Charcot-Marie-Tooth neuropathy type 1A with the $17 \mathrm{p} 11.2 \mathrm{p} 12$ duplication: a cross-sectional morphometric and immunohistochemical study in twenty cases. Muscle Nerve 1998;21(7):869-877.

36. Sturtz FG, Latour P, Mocquard Y, et al. Clinical and electrophysiological phenotype of a homozygously duplicated CharcotMarie-Tooth (type 1A) disease. Eur Neurol 1997;38(1):26-30.

37. Warner LE, Hilz MJ, Appel SH, et al. Clinical phenotypes of different MPZ $\left(\mathrm{P}_{0}\right)$ mutations may include Charcot-Marie-Tooth type 1B, Dejerine-Sottas, and congenital hypomyelination. Neuron 1996;17(3):451-460.

38. Wise CA, Garcia CA, Davis SN, et al. Molecular analyses of unrelated Charcot-Marie-Tooth (CMT) disease patients suggest a high frequency of the CMT1A duplication. Am J Hum Genet 1993;53(4):853-863.

39. Birouk N, Gouider R, Le Guern E, et al. Charcot-Marie-Tooth disease type $1 \mathrm{~A}$ with $17 \mathrm{p} 11.2$ duplication. Clinical and electrophysiological phenotype study and factors influencing disease severity in 119 cases. Brain 1997;120(Pt 5):813-823.

40. Thomas PK, Marques W Jr, Davis MB, et al. The phenotypic manifestations of chromosome 17p11.2 duplication. Brain 1997;120(Pt 3):465-478.

41. Blair IP, Nash J, Gordon MJ, Nicholson GA. Prevalence and origin of de novo duplications in Charcot-Marie-Tooth disease type 1A: first report of a de novo duplication with a maternal origin. Am J Hum Genet 1996;58(3):472-476.

42. Marrosu MG, Vaccargiu S, Marrosu G, et al. A novel point mutation in the peripheral myelin protein 22 (PMP22) gene associated with Charcot-Marie-Tooth disease type $1 \mathrm{~A}$. Neurology 1997;48(2):489-493.

43. Dyck PJ, Gutrecht JA, Bastron JA, Karnes WE, Dale AJ. Histologic and teased-fiber measurements of sural nerve in disorders of lower motor and primary sensory neurons. Mayo Clin Proc 1968;43(2):81-123.
44. Hoogendijk JE, De Visser M, Bolhuis PA, et al. Hereditary motor and sensory neuropathy type I: clinical and neurographical features of the 17p duplication subtype. Muscle Nerve 1994; 17(1):85-90.

45. Killian JM, Tiwari PS, Jacobson S, Jackson RD, Lupski JR. Longitudinal studies of the duplication form of Charcot-MarieTooth polyneuropathy. Muscle Nerve 1996;19(1):74-78.

46. Roy EPd, Gutmann L, Riggs JE. Longitudinal conduction studies in hereditary motor and sensory neuropathy type 1 . Muscle Nerve 1989;12(1):52-55.

47. Kaku DA, Parry GJ, Malamut R, Lupski JR, Garcia CA. Nerve conduction studies in Charcot-Marie-Tooth polyneuropathy associated with a segmental duplication of chromosome 17. Neurology 1993;43(9):1806-1808

48. Garcia A, Combarros O, Calleja J, Berciano J. Charcot-MarieTooth disease type $1 \mathrm{~A}$ with $17 \mathrm{p}$ duplication in infancy and early childhood: a longitudinal clinical and electrophysiologic study. Neurology 1998;50(4):1061-1067.

49. Nicholson GA. Penetrance of the hereditary motor and sensory neuropathy Ia mutation: assessment by nerve conduction studies. Neurology 1991;41(4):547-552.

50. Wilbourn AJ. Differentiating acquired from familial segmental demyelinating neuropathies by EMG. Electroencephalogr Clin Neurophysiol 1977;43:616A.

51. Lewis RA, Sumner AJ. The electrodiagnostic distinctions between chronic familial and acquired demyelinative neuropathies. Neurology 1982;32(6):592-596.

52. Kaku DA, Parry GJ, Malamut R, Lupski JR, Garcia CA. Uniform slowing of conduction velocities in Charcot-Marie-Tooth polyneuropathy type 1 . Neurology 1993;43(12):2664-2667.

53. Lewis RA, Sumner AJ, Shy ME. Electrophysiological features of inherited demyelinating neuropathies: a reappraisal in the era of molecular diagnosis. Muscle Nerve 2000;23(10):1472-1487.

54. Oh SJ, Chang CW. Conduction block and dispersion in hereditary motor and sensory neuropathy (abstract). Muscle Nerve 1987; 10:656A.

55. Hoogendijk JE, de Visser M, Bour LJ, Jennekens FG, Ongerboer BW. Conduction block in hereditary motor and sensory neuropathy type I [letter]. Muscle Nerve 1992;15(4):520-521.

56. Dyck PJ, Karnes JL, Lambert EH. Longitudinal study of neuropathic deficits and nerve conduction abnormalities in hereditary motor and sensory neuropathy type 1 . Neurology 1989;39(10):1302-1308.

57. Gabreels-Festen AA, Joosten EM, Gabreels FJ, Jennekens FG, Janssen-van Kempen TW. Early morphological features in dominantly inherited demyelinating motor and sensory neuropathy (HMSN type I). J Neurol Sci 1992;107(2):145-154

58. Behse F, Buchthal F. Peroneal muscular atrophy (PMA) and related disorders. II. Histological findings in sural nerves. Brain 1977; 100 (Pt 1):67-85.

59. Ouvrier RA, McLeod JG, Conchin TE. The hypertrophic forms of hereditary motor and sensory neuropathy. A study of hypertrophic Charcot-Marie-Tooth disease (HMSN type I) and Dejerine-Sottas disease (HMSN type III) in childhood. Brain 1987;110(Pt 1):121-148.

60. Gabreels-Festen AA, Bolhuis PA, Hoogendijk JE, et al. CharcotMarie-Tooth disease type 1A: morphological phenotype of the $17 \mathrm{p}$ duplication versus PMP22 point mutations. Acta Neuropathol 1995;90(6):645-649.

61. Dyck PJ. Histologic measurements and fine structure of biopsied sural nerve: normal, and in peroneal muscular atrophy, hypertrophic neuropathy, and congenital sensory neuropathy. Mayo Clin Proc 1966;41(11):742-774.

62. Dyck PJ, Chance P, Lebo R, Carney JA. Hereditary motor and sensory neuropathies. In: Dyck PJ, Thomas PK, eds. Peripheral Neuropathy. 3 Ed. Philadelphia: W. B. Saunders; 1993;1094-1136.

63. Gabreels-Festen A, Wetering RV. Human nerve pathology caused by different mutational mechanisms of the PMP22 gene. Ann N Y Acad Sci 1999;883:336-343.

64. Nukada H, Dyck PJ, Karnes JL. Thin axons relative to myelin spiral length in hereditary motor and sensory neuropathy, type I. Ann Neurol 1983;14(6):648-655. 
65. Nukada H, Dyck PJ. Decreased axon caliber and neurofilaments in hereditary motor and sensory neuropathy, type I. Ann Neurol 1984;16(2):238-241.

66. Latour $\mathrm{P}, \mathrm{Blanquet} \mathrm{F}$, Nelis $\mathrm{E}$, et al. Mutations in the myelin protein zero gene associated with Charcot-Marie-Tooth disease type 1B. Hum Mutat 1995;6(1):50-54.

67. Bird TD, Kraft GH, Lipe HP, Kenney KL, Sumi SM. Clinical and pathological phenotype of the original family with CharcotMarie-Tooth type 1B: a 20-year study. Ann Neurol 1997;41(4): 463-469.

68. Plante-Bordeneuve V, Guiochon-Mantel A, Lacroix C, Lapresle J, Said G. The Roussy-Levy family: from the original description to the gene. Ann Neurol 1999;46(5):770-773.

69. Gabreels-Festen AA, Hoogendijk JE, Meijerink PH, et al. Two divergent types of nerve pathology in patients with different $\mathrm{P} 0$ mutations in Charcot-Marie-Tooth disease. Neurology 1996; 47(3):761-765

70. Filbin MT, Walsh FS, Trapp BD, Pizzey JA, Tennekoon GI. Role of myelin $\mathrm{P} 0$ protein as a homophilic adhesion molecule. Nature 1990;344(6269):871-872.

71. Roussy G, Lévy G. Sept cas d'une maladie familiale particulière: troubles de la marche, pieds bots et aréflexie tendineuse généralisée, avec, accessoirement, légére maladresse des mains. Rev Neurol 1926;1:427-450.

72. Senderek J, Hermanns B, Bergmann C, et al. X-linked dominant Charcot-Marie-Tooth neuropathy: clinical, electrophysiological, and morphological phenotype in four families with different connexin32 mutations(1). J Neurol Sci 1999;167(2): 90-101.

73. Dalakas MC, Teravainen H, Engel WK. Tremor as a feature of chronic relapsing and dysgammaglobulinemic polyneuropathies. Incidence and management. Arch Neurol 1984;41(7):711714.

74. Pedersen SF, Pullman SL, Latov N, Brannagan TH, 3rd. Physiological tremor analysis of patients with anti-myelinassociated glycoprotein associated neuropathy and tremor. Muscle Nerve 1997;20(1):38-44.

75. Timmerman V, De Jonghe P, Spoelders P, et al. Linkage and mutation analysis of Charcot-Marie-Tooth neuropathy type 2 families with chromosomes 1p35-p36 and Xq13. Neurology 1996;46(5):1311-1318.

76. Ben Othmane K, Middleton LT, Loprest LJ, et al. Localization of a gene (CMT2A) for autosomal dominant Charcot-Marie- Tooth disease type 2 to chromosome $1 \mathrm{p}$ and evidence of genetic heterogeneity. Genomics 1993;17(2):370-375.

77. Kwon JM, Elliott JL, Yee WC, et al. Assignment of a second Charcot-Marie-Tooth type II locus to chromosome 3q. Am J Hum Genet 1995;57(4):853-858.

78. De Jonghe P, Timmerman V, FitzPatrick D, et al. Mutilating neuropathic ulcerations in a chromosome 3q13-q22 linked Charcot-Marie-Tooth disease type 2B family. J Neurol Neurosurg Psychiatry 1997;62(6):570-573.

79. Ionasescu V, Searby C, Sheffield VC, et al. Autosomal dominant Charcot-Marie-Tooth axonal neuropathy mapped on chromosome 7p (CMT2D). Hum Mol Genet 1996;5(9):13731375 .

80. Mersiyanova IV, Perepelov AV, Polyakov AV, et al. A new variant of Charcot-Marie-Tooth disease type 2 is probably the result of a mutation in the neurofilament-light gene. Am J Hum Genet 2000;67(1):37-46

81. Dyck PJ, Litchy WJ, Minnerath S, et al. Hereditary motor and sensory neuropathy with diaphragm and vocal cord paresis. Ann Neurol 1994;35(5):608-615.

82. Friedman HC, Jelsma TN, Bray GM, Aguayo AJ. A distinct pattern of trophic factor expression in myelin-deficient nerves of Trembler mice: implications for trophic support by Schwann cells. J Neurosci 1996;16(17):5344-5350.

83. Marrosu MG, Vaccargiu S, Marrosu G, et al. Charcot-Marie-Tooth disease type 2 associated with mutation of the myelin protein zero gene. Neurology 1998;50(5):1397-1401.

84. Chapon F, Latour P, Diraison P, Schaeffer S, Vandenberghe A. Axonal phenotype of Charcot-Marie-Tooth disease associated with a mutation in the myelin protein zero gene. J Neurol Neurosurg Psychiatry 1999;66(6):779-782.

85. De Jonghe P, Timmerman V, Ceuterick C, et al. The Thr124Met mutation in the peripheral myelin protein zero (MPZ) gene is associated with a clinically distinct Charcot-Marie-Tooth phenotype. Brain 1999;122(Pt 2):281-290.

86. Harding AE, Thomas PK. Hereditary distal spinal muscular atrophy. A report on 34 cases and a review of the literature. J Neurol Sci 1980;45(2-3):337-348.

87. Nicholson G, Nash J. Intermediate nerve conduction velocities define X-linked Charcot-Marie- Tooth neuropathy families. Neurology 1993;43(12):2558-2564.

88. Rouger H, LeGuern E, Birouk N, et al. Charcot-Marie-Tooth disease with intermediate motor nerve conduction velocities: characterization of $14 \mathrm{Cx} 32$ mutations in 35 families. Hum Mutat 1997;10(6):443-452.

89. Birouk N, LeGuern E, Maisonobe T, et al. X-linked Charcot-MarieTooth disease with connexin 32 mutations: clinical and electrophysiologic study. Neurology 1998;50(4):1074-1082.

90. Hahn AF, Bolton CF, White CM, et al. Genotype/phenotype correlations in X-linked dominant Charcot-Marie- Tooth disease. Ann N Y Acad Sci 1999;883:366-382.

91. Berciano J, Combarros O, Figols J, et al. Hereditary motor and sensory neuropathy type II. Clinicopathological study of a family. Brain 1986;109(Pt 5):897-914.

92. Vogel P, Gabriel M, Goebel HH, Dyck PJ. Hereditary motor sensory neuropathy type II with neurofilament accumulation: new finding or new disorder? Ann Neurol 1985;17(5):455-461.

93. Silander K, Meretoja P, Pihko H, et al. Screening for connexin 32 mutations in Charcot-Marie-Tooth disease families with possible X-linked inheritance. Hum Genet 1997;100(3-4):391-397.

94. Bergoffen J, Scherer SS, Wang S, et al. Connexin mutations in Xlinked Charcot-Marie-Tooth disease. Science 1993;262(5142): 2039-2042.

95. Meggouh F, Benomar A, Rouger $\mathrm{H}$, et al. The first de novo mutation of the connexin 32 gene associated with X-linked Charcot-Marie-Tooth disease. J Med Genet 1998;35(3):251252.

96. Niewiadomski LA, Kelly TE. X-linked Charcot-Marie-Tooth disease: molecular analysis of interfamilial variability. Am J Med Genet 1996;66(2):175-178

97. Ionasescu VV, Trofatter J, Haines JL, Ionasescu R, Searby C. Mapping of the gene for X-linked dominant Charcot-MarieTooth neuropathy. Neurology 1992;42(4):903-908.

98. Scherer SS, Xu YT, Nelles E, et al. Connexin32-null mice develop demyelinating peripheral neuropathy. Glia 1998;24(1):8-20.

99. Bahr M, Andres F, Timmerman V, et al. Central visual, acoustic, and motor pathway involvement in a Charcot-Marie-Tooth family with an Asn205Ser mutation in the connexin 32 gene. J Neurol Neurosurg Psychiatry 1999;66(2):202-206.

100. Hahn AF, Ainsworth PJ, Naus CC, Mao J, Bolton CF. Clinical and pathological observations in men lacking the gap junction protein connexin 32. Muscle Nerve 2000;999(9):S39-S48.

101. Lewis RA, Shy ME. Electrodiagnostic findings in CMTX: a disorder of the Schwann cell and peripheral nerve myelin. Ann N Y Acad Sci 1999;883:504-507.

102. Tabaraud F, Lagrange E, Sindou P, et al. Demyelinating X-linked Charcot-Marie-Tooth disease: unusual electrophysiological findings. Muscle Nerve 1999;22:1442-1447.

103. Gutierrez A, England JD, Sumner AJ, et al. Unusual electrophysiological findings in X-linked dominant CharcotMarie-Tooth disease. Muscle Nerve 2000;23(2):182-188.

104. Sander S, Nicholson GA, Ouvrier RA, McLeod JG, Pollard JD. Charcot-Marie-Tooth disease: histopathological features of the peripheral myelin protein (PMP22) duplication (CMT 1A) and connexin32 mutations (CMTX1). Muscle Nerve 1998;21(2):217-225

105. Sahenk Z, Chen L. Abnormalities in the axonal cytoskeleton induced by a connexin 32 mutation in nerve xenografts. J Neurosci Res 1998;51(2): 174-184.

106. Davies DM. Recurrent peripheral-nerve palsies in a family. Lancet $1954 ; 2: 226-268$ 
107. Behse F, Buchthal F, Carlsen F, Knappeis GG. Hereditary neuropathy with liability to pressure palsies. Electrophysiological and histopathological aspects. Brain 1972;95(4):777-794.

108. Chance PF, Alderson MK, Leppig KA, et al. DNA deletion associated with hereditary neuropathy with liability to pressure palsies. Cell 1993;72(1):143-151.

109. Mariman EC, Gabreels-Festen AA, van Beersum SE, et al. Prevalence of the $1.5-\mathrm{Mb} 17 \mathrm{p}$ deletion in families with hereditary neuropathy with liability to pressure palsies. Ann Neurol 1994;36(4):650-655.

110. Meretoja P, Silander K, Kalimo H, et al. Epidemiology of hereditary neuropathy with liability to pressure palsies (HNPP) in south western Finland. Neuromuscul Disord 1997;7(8):529-532.

111. Tyson J, Malcolm S, Thomas PK, Harding AE. Deletions of chromosome 17p11.2 in multifocal neuropathies. Ann Neurol 1996;39(2):180-186.

112. Pareyson D, Scaioli V, Taroni F, et al. Phenotypic heterogeneity in hereditary neuropathy with liability to pressure palsies associated with chromosome 17p11.2-12 deletion. Neurology 1996;46(4):1133-1137.

113. Gil-Neciga E, Franco E, Sanchez A, et al. Recurrent familial brachial plexopathy as the only clinical expression of neuropathy with susceptibility to pressure. Neurologia 2000; 15(4):177-181.

114. Mouton P, Tardieu S, Gouider R, et al. Spectrum of clinical and electrophysiologic features in HNPP patients with the $17 \mathrm{p} 11.2$ deletion. Neurology 1999;52(7):1440-1446.

115. Windebank AJ, Schenone A, Dewald GW. Hereditary neuropathy with liability to pressure palsies and inherited brachial plexus neuropathy--two genetically distinct disorders. Mayo Clin Proc 1995;70(8):743-746.

116. Pellegrino JE, George RA, Biegel J, et al. Hereditary neuralgic amyotrophy: evidence for genetic homogeneity and mapping to chromosome 17q25. Hum Genet 1997;101(3):277-283.

117. Stogbauer F, Young P, Timmerman V, et al. Refinement of the hereditary neuralgic amyotrophy (HNA) locus to chromosome 17q24-q25. Hum Genet 1997;99(5):685-687.

118. Le Forestier N, LeGuern E, Coullin P, et al. Recurrent polyradiculoneuropathy with the $17 \mathrm{p} 11.2$ deletion. Muscle Nerve 1997;20(9):1184-1186.

119. Crum BA, Sorenson EJ, Abad GA, Dyck PJ. Fulminant case of hereditary neuropathy with liability to pressure palsy. Muscle Nerve 2000;23(6):979-983.

120. Magistris MR, Roth G. Long-lasting conduction block in hereditary neuropathy with liability to pressure palsies. Neurology 1985;35(11):1639-1641.

121. Uncini A, Di Guglielmo G, Di Muzio A, et al. Differential electrophysiological features of neuropathies associated with 17p11.2 deletion and duplication. Muscle Nerve 1995;18(6): 628-635.

122. Amato AA, Gronseth GS, Callerame KJ, et al. Tomaculous neuropathy: a clinical and electrophysiological study in patients with and without $1.5-\mathrm{Mb}$ deletions in chromosome 17p11.2. Muscle Nerve 1996;19(1):16-22.

123. Andersson PB, Yuen E, Parko K, So YT. Electrodiagnostic features of hereditary neuropathy with liability to pressure palsies. Neurology 2000;54(1):40-44.

124. Verhagen WI, Gabreels-Festen AA, van Wensen PJ, et al. Hereditary neuropathy with liability to pressure palsies: a clinical, electroneurophysiological and morphological study. J Neurol Sci 1993;116(2):176-184.

125. Gouider R, LeGuern E, Gugenheim M, et al. Clinical, electrophysiologic, and molecular correlations in 13 families with hereditary neuropathy with liability to pressure palsies and a chromosome 17p11.2 deletion. Neurology 1995;45(11):2018-2023.

126. Madrid R, Bradley WG. The pathology of neuropathies with focal thickening of the myelin sheath (tomaculous neuropathy). J Neurol Sci 1975;25:415-448.

127. Yoshikawa H, Dyck PJ. Uncompacted inner myelin lamellae in inherited tendency to pressure palsy. J Neuropathol Exp Neurol 1991;50(5):649-657.

128. Behse F, Buchthal F, Carlsen F, Knappeis GG. Conduction and histopathology of the sural nerve in hereditary neuropathy with liability to pressure palsies. In: Desmedt JE, ed. New Developments in Electromyography and Clinical Neurophysiology. Basel: S. Karger; 1973; 286.

129. Hayasaka K, Himoro M, Sawaishi Y, et al. De novo mutation of the myelin $\mathrm{P}_{0}$ gene in Dejerine-Sottas disease (hereditary motor and sensory neuropathy type III). Nat Genet 1993;5(3):266-268.

130. Rautenstrauss B, Nelis E, Grehl H, Pfeiffer RA, Van Broeckhoven C. Identification of a de novo insertional mutation in $\mathrm{P} 0$ in a patient with a Dejerine-Sottas syndrome (DSS) phenotype. Hum Mol Genet 1994;3(9):1701-1702.

131. Roa BB, Dyck PJ, Marks HG, Chance PF, Lupski JR. DejerineSottas syndrome associated with point mutation in the peripheral myelin protein 22 (PMP22) gene. Nat Genet 1993;5(3):269-273.

132. Marques W Jr, Thomas PK, Sweeney MG, Carr L, Wood NW. Dejerine-Sottas neuropathy and PMP22 point mutations: a new base pair substitution and a possible "hot spot" on Ser72. Ann Neurol 1998;43(5):680-683.

133. Killian JM, Kloepfer HW. Homozygous expression of a dominant gene for Charcot-Marie-Tooth neuropathy. Ann Neurol 1979; 5(6):515-522.

134. Ikegami $T$, Nicholson $G$, Ikeda $H$, et al. A novel homozygous mutation of the myelin $\mathrm{P}_{0}$ gene producing Dejerine-Sottas disease (hereditary motor and sensory neuropathy type III). Biochem Biophys Res Commun 1996;222(1):107-110.

135. Benstead TJ, Kuntz NL, Miller RG, Daube JR. The electrophysiologic profile of Dejerine-Sottas disease (HMSN III). Muscle Nerve 1990;13(7):586-592.

136. Gabreels-Festen AA, Gabreels FJ, Jennekens FG, Janssen-van Kempen TW. The status of HMSN type III. Neuromusc Disord 1994;4(1):63-69.

137. Lyon G. Ultrastructural study of a nerve biopsy from a case of early infantile chronic neuropathy. Acta Neuropathol 1969;13(2):131142 .

138. Joosten E, Gabreels F, Gabreels-Festen A, et al. Electronmicroscopic heterogeneity of onion-bulb neuropathies of the Dejerine-Sottas type. Two patients in one family with the variant described by Lyon (1969). Acta Neuropathol (Berl) 1974;27(2):105-118.

139. Kennedy WR, Sung JH, Berry JF. A case of congenital hypomyelination neuropathy. Clinical, morphological, and chemical studies. Arch Neurol 1977;34:337-345.

140. Guzzetta F, Ferriere G, Lyon G. Congenital hypomyelination polyneuropathy. Pathological findings compared with polyneuropathies starting later in life. Brain 1982;105(Pt 2):395-416

141. Ben Othmane K, Hentati F, Lennon F, et al. Linkage of a locus (CMT4A) for autosomal recessive Charcot-Marie-Tooth disease to chromosome 8q. Hum Mol Genet 1993;2(10):1625-1628.

142. Bolino A, Brancolini V, Bono F, et al. Localization of a gene responsible for autosomal recessive demyelinating neuropathy with focally folded myelin sheaths to chromosome $11 \mathrm{q} 23$ by homozygosity mapping and haplotype sharing. Hum Mol Genet 1996;5(7):1051-1054.

143. LeGuern E, Guilbot A, Kessali M, et al. Homozygosity mapping of an autosomal recessive form of demyelinating Charcot-MarieTooth disease to chromosome 5q23-q33. Hum Mol Genet 1996; 5(10):1685-1688.

144. Gabreels-Festen A, van Beersum S, Eshuis L, et al. Study on the gene and phenotypic characterisation of autosomal recessive demyelinating motor and sensory neuropathy (Charcot-MarieTooth disease) with a gene locus on chromosome 5q23-q33. J Neurol Neurosurg Psychiatry 1999;66(5):569-574.

145. Kalaydjieva L, Hallmayer J, Chandler D, et al. Gene mapping in Gypsies identifies a novel demyelinating neuropathy on chromosome 8q24. Nat Genet 1996;14(2):214-217.

146. Delague V, Bareil C, Tuffery S, et al. Mapping of a new locus for autosomal recessive demyelinating Charcot-Marie-Tooth disease to $19 \mathrm{q} 13.1-13.3$ in a large consanguineous Lebanese family: exclusion of MAG as a candidate gene. Am J Hum Genet 2000;67(1):236-243. 
147. Bouhouche A, Benomar A, Birouk N, et al. A locus for an axonal form of autosomal recessive Charcot-Marie-Tooth disease maps to chromosome 1q21.2-q21.3. Am J Hum Genet 1999;65(3): 722-727.

148. Leal A, Morera B, Del Valle G, et al. A Second Locus for an Axonal Form of Autosomal Recessive Charcot-Marie- Tooth Disease Maps to Chromosome 19q13.3. Am J Hum Genet 2000;68(1).

149. Quattrone A, Gambardella A, Bono F, et al. Autosomal recessive hereditary motor and sensory neuropathy with focally folded myelin sheaths: clinical, electrophysiologic, and genetic aspects of a large family. Neurology 1996;46:1318-1324.

150. Vallat JM, Gil R, Leboutet MJ, Hugon J, Moulies D. Congenital hypo- and hypermyelination neuropathy. Two cases. Acta Neuropathol 1987;74(2):197-201.

151. Ohnishi A, Murai Y, Ikeda M, et al. Autosomal recessive motor and sensory neuropathy with excessive myelin outfolding. Muscle Nerve 1989;12(7):568-575.

152. Gabreels-Festen AA, Joosten EM, Gabreels FJ, et al. Congenital demyelinating motor and sensory neuropathy with focally folded myelin sheaths. Brain 1990;113:1629-1643.

153. Sabatelli M, Mignogna T, Lippi G, et al. Autosomal recessive hypermyelinating neuropathy. Acta Neuropathol 1994;87(4):337-342.

154. Schenone A, Abbruzzese M, Uccelli A, et al. Hereditary motor and sensory neuropathy with myelin outfolding: clinical, genetic and neuropathological study of three cases [published erratum appears in J Neurol Sci 1994 Sep;125(2):215]. J Neurol Sci 1994;122(1):20-27.

155. Barbieri F, Santangelo R, Capparelli G, Ciccarelli A, Crisci C. Autosomal recessive motor and sensory neuropathy with excessive myelin outfolding in two siblings. Can J Neurol Sci 1994;21(1):29-33.

156. Kessali M, Zemmouri R, Guilbot A, et al. A clinical, electrophysiologic, neuropathologic, and genetic study of two large Algerian families with an autosomal recessive demyelinating form of Charcot-Marie-Tooth disease. Neurology 1997;48(4):867-873.

157. Umehara F, Takenaga S, Nakagawa M, et al. Dominantly inherited motor and sensory neuropathy with excessive myelin folding complex. Acta Neuropathol 1993;86(6):602-608.

158. Nakagawa M, Suehara M, Saito A, et al. A novel MPZ gene mutation in dominantly inherited neuropathy with focally folded myelin sheaths. Neurology 1999;52(6):1271-1275.

159. Ring HZ, Chang H, Guilbot A, et al. The human neuregulin-2 (NRG2) gene: cloning, mapping and evaluation as a candidate for the autosomal recessive form of Charcot-Marie-Tooth disease linked to 5q. Hum Genet 1999;104(4):326-332. 